\title{
Optical properties and molecular compositions of water-soluble and water-insoluble brown carbon (BrC) aerosols in northwest China
}

\author{
Jianjun Li $i^{1,2}$, Qi Zhang ${ }^{2}$, Gehui Wang ${ }^{1,3,4}$, Jin Li ${ }^{1}$, Can Wu ${ }^{1,3}$, Lang Liu ${ }^{1}$, Jiayuan Wang ${ }^{1,2}$, Wenqing Jiang ${ }^{2}$, \\ Lijuan Li ${ }^{1,2}$, Kin Fai Ho ${ }^{1,5}$, and Junji Cao ${ }^{1}$ \\ ${ }^{1}$ Key Lab of Aerosol Chemistry \& Physics, SKLLQG, Institute of Earth Environment, \\ Chinese Academy of Sciences, Xi' an 710061, China \\ ${ }^{2}$ Department of Environmental Toxicology, University of California, Davis, CA 95616, USA \\ ${ }^{3}$ Key Laboratory of Geographic Information Science of the Ministry of Education, \\ School of Geographic Sciences, East China Normal University, Shanghai 200241, China \\ ${ }^{4}$ Institute of Eco-Chongming, 3663 N. Zhongshan Rd., Shanghai 200062, China \\ ${ }^{5}$ The Jockey Club School of Public Health and Primary Care, \\ The Chinese University of Hong Kong, Hong Kong, China
}

Correspondence: Qi Zhang (dkwzhang@ucdavis.edu) and Gehui Wang (ghwang@geo.ecnu.edu.cn)

Received: 30 October 2019 - Discussion started: 5 December 2019

Revised: 19 March 2020 - Accepted: 27 March 2020 - Published: 27 April 2020

\begin{abstract}
Brown carbon $(\mathrm{BrC})$ contributes significantly to aerosol light absorption and thus can affect the Earth's radiation balance and atmospheric photochemical processes. In this study, we examined the light absorption properties and molecular compositions of water-soluble (WS-BrC) and water-insoluble (WI-BrC) $\mathrm{BrC}$ in $\mathrm{PM}_{2.5}$ collected from a rural site in the Guanzhong Basin - a highly polluted region in northwest China. Both WS-BrC and WI-BrC showed elevated light absorption coefficients (Abs) in winter (4-7 times those in summer) mainly attributed to enhanced emissions from residential biomass burning (BB) for heating of homes. While the average mass absorption coefficients (MACs) at $365 \mathrm{~nm}\left(\mathrm{MAC}_{365}\right)$ of WS-BrC were similar between daytime and nighttime in summer $\left(0.99 \pm 0.17\right.$ and $1.01 \pm 0.18 \mathrm{~m}^{2} \mathrm{~g}^{-1}$, respectively), the average $\mathrm{MAC}_{365}$ of WI-BrC was more than a factor of 2 higher during daytime $\left(2.45 \pm 1.14 \mathrm{~m}^{2} \mathrm{~g}^{-1}\right)$ than at night $\left(1.18 \pm 0.36 \mathrm{~m}^{2} \mathrm{~g}^{-1}\right)$. This difference was partly attributed to enhanced photochemical formation of WI-BrC species, such as oxygenated polycyclic aromatic hydrocarbons (OPAHs). In contrast, the MACs of WS-BrC and WI$\mathrm{BrC}$ were generally similar in winter and both showed few diel differences. The Abs of wintertime WS-BrC correlated strongly with relative humidity, sulfate and $\mathrm{NO}_{2}$, suggesting that aqueous-phase reaction is an important pathway for secondary $\mathrm{BrC}$ formation during the winter season in northwest
\end{abstract}

China. Nitrophenols on average contributed $2.44 \pm 1.78 \%$ of the Abs of WS-BrC in winter but only $0.12 \pm 0.03 \%$ in summer due to faster photodegradation reactions. WS-BrC and WI-BrC were estimated to account for $0.83 \pm 0.23 \%$ and $0.53 \pm 0.33 \%$, respectively, of the total down-welling solar radiation in the ultraviolet (UV) range in summer, and $1.67 \pm 0.72 \%$ and $2.07 \pm 1.24 \%$, respectively, in winter. The total absorption by $\mathrm{BrC}$ in the $\mathrm{UV}$ region was about $55 \%$ $79 \%$ relative to the elemental carbon (EC) absorption.

\section{Introduction}

Light-absorbing organic matter, termed brown carbon $(\mathrm{BrC})$, has been recognized as an important climate forcer due to its ability to directly interact with both incoming solar radiation and outgoing terrestrial radiation (Andreae and $\mathrm{Ge}$ lencser, 2006; Laskin et al., 2015). BrC is a complex mixture of organic compounds, which collectively show a light absorption profile increasing exponentially from the visible (Vis) to the ultraviolet (UV) range. Due to the high abundance of organic aerosol in continental regions, especially in places with intensive anthropogenic pollution, the contribution of $\mathrm{BrC}$ to aerosol absorption in the near-UV range is potentially significant (Kirillova et al., 2014b; Huang et al., 
2018; Yan et al., 2015a). For example, a model study showed that $\mathrm{BrC}$ contributes up to $+0.25 \mathrm{~W} \mathrm{~m}^{-2}$ of radiative forcing on a planetary scale, which is approximately $19 \%$ of the absorption by anthropogenic aerosols (Feng et al., 2013). Moreover, the strong absorption of $\mathrm{BrC}$ in the UV spectral region can reduce the solar actinic flux and subsequently affect atmospheric photochemistry and tropospheric ozone production (Jacobson, 1998; Mohr et al., 2013).

A thorough understanding of the sources and transformation processes of $\mathrm{BrC}$ in the atmosphere is important, but it is still lacking. Biomass and biofuel combustion, including forest fires and burning of wood and agricultural wastes for residential cooking and heating, has been shown to be a particularly important source of $\mathrm{BrC}$ (Washenfelder et al., 2015; Desyaterik et al., 2013; Lin et al., 2017). BrC can also be emitted directly from coal burning (Yan et al., 2017) and biogenic release of fungi, plant debris and humic matter (Rizzo et al., 2011, 2013). In addition, recent studies suggested that secondary $\mathrm{BrC}$ can be formed through various reaction pathways, including photooxidation of aromatic volatile organic compounds (VOCs) (Lin et al., 2015; Liu et al., 2016), reactive uptake of isoprene epoxydiols onto preexisting sulfate aerosols (Lin et al., 2014), aqueous oxidation of phenolic compounds and $\alpha$-dicarbonyls (Chang and Thompson, 2010; Nozière and Esteve, 2005; Smith et al., 2016; Yu et al., 2014; Xu et al., 2018), and reactions of ammonia or amines with carbonyl compounds in particles or cloud droplets (Nozière et al., 2007; Laskin et al., 2010; Updyke et al., 2012; Nguyen et al., 2012; De Haan et al., 2018; Powelson et al., 2014). However, atmospheric oxidation processes may also cause "photobleach" - photodegradation of BrC into lesslight-absorbing compounds (Lee et al., 2014; Romonosky et al., 2015; Sumlin et al., 2017), which may complicate the understanding of $\mathrm{BrC}$ in the atmosphere.

A common way to quantify the absorption properties of $\mathrm{BrC}$ is to measure the absorbance of aerosol extracts over a wide wavelength range using spectrophotometers. This approach can differentiate the interference of black carbon (BC) or mineral dust (Hecobian et al., 2010). Most of the studies use ultrapure water to extract organic substance in the aerosol and thus measure the optical properties of watersoluble BrC (WS-BrC) (Wu et al., 2019; Hecobian et al., 2010; Kirillova et al., 2014b). In addition, some studies analyzed the light absorption of $\mathrm{BrC}$ extracted using polar organic solvents such as methanol or acetone (Liu et al., 2013; Huang et al., 2018; Kim et al., 2016). Since such extracts contain both water-soluble and water-insoluble chromophores, little information is available regarding the contribution and formation of water-insoluble $\mathrm{BrC}$ (WI-BrC). However, it is important to understand WI-BrC given the fact that some water-insoluble organic compounds, such as polycyclic aromatic hydrocarbons and their derivatives, are effective light absorbers and that the mass absorption of WI$\mathrm{BrC}$ could be even greater than that of the water-soluble fraction (Chen and Bond, 2010; Huang et al., 2018; Sengupta et al., 2018). Thus, it is necessary to extract water-soluble and water-insoluble organic components separately, e.g., using solvents with different polarity in sequence. Combining with measurements of $\mathrm{BrC}$ molecular compositions, the UV-vis absorption properties of the water-soluble and waterinsoluble extracts may help us better understand the sources and formation mechanisms of light-absorbing compounds in the atmosphere.

China has been experiencing serious atmospheric pollution conditions in recent decades, and both model and field results showed elevated light absorption of $\mathrm{BrC}$ in most regions of China (Huang et al., 2018; Cheng et al., 2011; Yan et al., 2017; Li et al., 2016b) compared to developed countries such as the US (Hecobian et al., 2010; Washenfelder et al., 2015) and European countries (Mohr et al., 2013; Teich et al., 2017). However, BrC-related data are scarce in the Guanzhong Basin (Shen et al., 2017; Huang et al., 2018), which is one of the most polluted regions in China (van Donkelaar et al., 2010). Here we present measurements of the optical properties of WS-BrC and WI-BrC in $\mathrm{PM}_{2.5}$ collected from a rural area of the Guanzhong Basin during winter and summer. We also measured the concentrations of several $\mathrm{BrC}$ compounds as well as those of organic carbon (OC), elemental carbon (EC), water-soluble OC (WSOC) and inorganic ions. These data were analyzed to examine the effects of source emissions, daytime photochemical oxidation and aqueous-phase chemistry on WS-BrC and WI-BrC components in different seasons.

\section{Experimental section}

\subsection{Sample collection}

The sampling was conducted at a small village (namely Lincun, $34^{\circ} 44^{\prime} \mathrm{N}$ and $109^{\circ} 32^{\prime} \mathrm{E}, 354 \mathrm{~m}$ a.s.l.) $\sim 40 \mathrm{~km}$ northeast of Xi' an, the capital of Shaanxi Province (Fig. S1 in the Supplement). The sampling site is located in the central part of Guanzhong Basin with no obvious point source of air pollutants in the surrounding areas. $\mathbf{P M}_{2.5}$ samples were collected twice a day ( $\sim$ 08:00 to 20:00 and $\sim 20: 00$ to 08:00) onto prebaked $\left(450{ }^{\circ} \mathrm{C}, 6-8 \mathrm{~h}\right)$ quartz fiber filters (Whatman, QMA, USA) during 3-23 August 2016 and 20 January-1 February 2017 using a Tisch Environmental (USA) $\mathrm{PM}_{2.5}$ highvolume $\left(1.13 \mathrm{~m}^{3} \mathrm{~min}^{-1}\right)$ sampler. Field blank samples were also collected by mounting blank filters onto the sampler for about 15 min without pumping any air. After sampling, the sample filters were immediately sealed in aluminum foil bags and then stored in a freezer $\left(-5^{\circ} \mathrm{C}\right)$ prior to analysis. Meteorological conditions and concentrations of $\mathrm{O}_{3}$ and $\mathrm{NO}_{2}$ during this studied period are presented in Fig. 1.

\subsection{Filter extraction and absorption spectra analysis}

For each $\mathrm{PM}_{2.5}$ sample, a portion of the filter $\left(\sim 13.384 \mathrm{~cm}^{2}\right)$ was first extracted in $8 \mathrm{~mL}$ of Milli-Q water $(18.2 \mathrm{M} \Omega)$ 

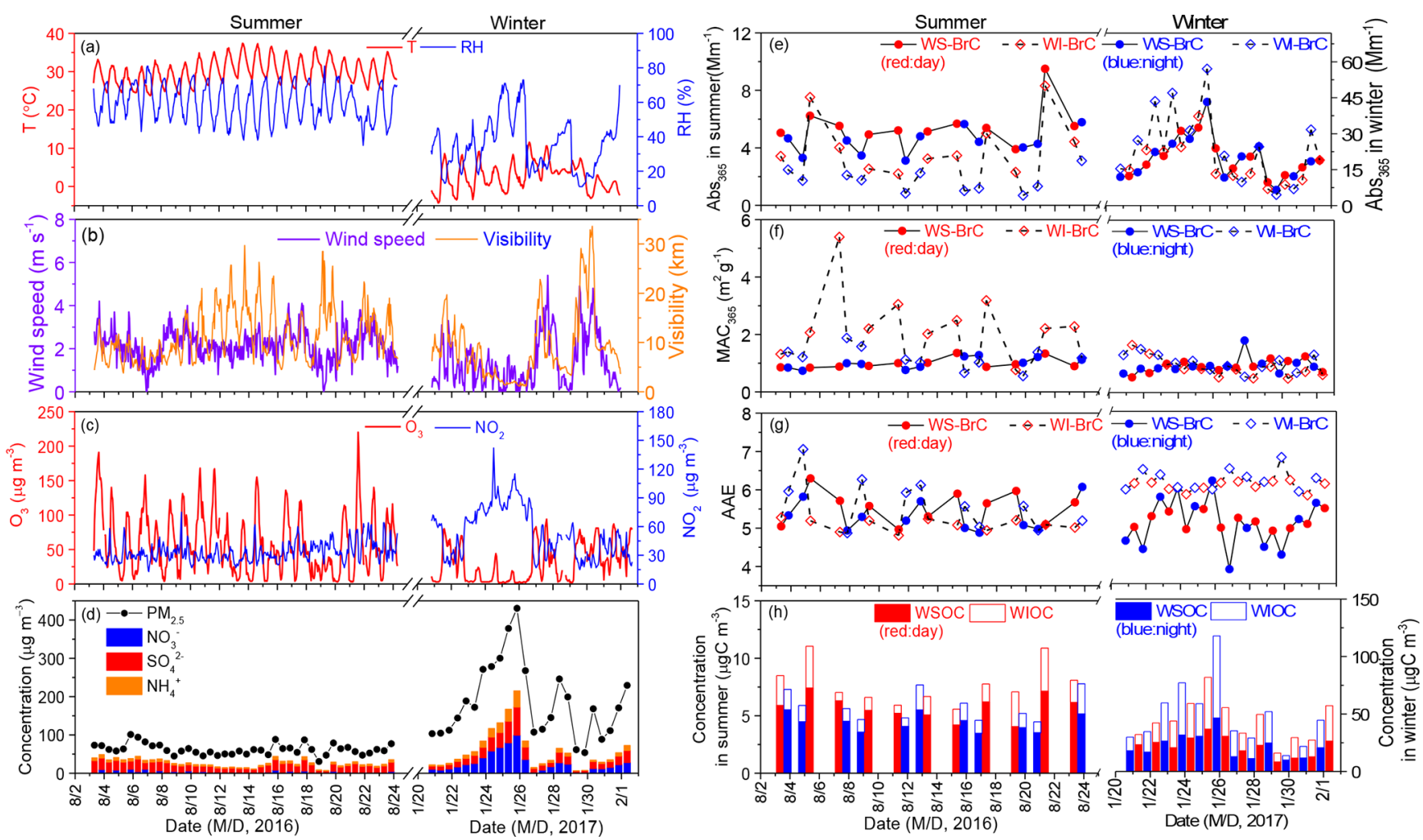

Figure 1. Temporal variation in meteorological parameters $(\mathbf{a}, \mathbf{b})$ and concentrations of major chemical compositions, $\mathrm{Abs}_{365}, \mathrm{MAC}_{365}$ and $\mathrm{AAE}$ of water-soluble and water-insoluble $\mathrm{BrC}$ in $\mathrm{PM}_{2.5}$ from the rural area of northwest China.

through $30 \mathrm{~min}$ of sonication at $\sim 0^{\circ} \mathrm{C}$. The water extract was then filtered via vacuum filtration with a $25 \mathrm{~mm}$ diameter, $5 \mu \mathrm{m}$ pore hydrophobic PTFE membrane filter (Merck Millipore Ltd, Mitex ${ }^{\mathrm{TM}}$ membrane filters, USA). Afterwards, the insoluble PM components collected on the PTFE membrane filter and remained on the sample filter were rinsed with $2 \mathrm{~mL}$ of Milli-Q water, air-dried and then extracted via sonication in $8 \mathrm{~mL}$ of pure acetonitrile (ACN) (Honeywell Burdick \& Jackson, LC/MS grade, USA). The acetonitrile extract was filtered via a $13 \mathrm{~mm}$ diameter, $0.45 \mu \mathrm{m}$ pore syringe filter (Pall, Bulk Acrodisc ${ }^{\circledR}$, PTFE membrane filters, USA). The light absorption spectra of the water and the acetonitrile extracts were measured between 190 and $820 \mathrm{~nm}$ by a diode-array spectrophotometer (Hewlett Packard 8452A, USA) using quartz cuvettes with $1 \mathrm{~cm}$ length path. Field blank filters were extracted and measured in the same manner as the samples. Data presented in this study were corrected for the field blanks $(<10 \%$ relative to field samples).

\subsection{Chemical analysis}

OC and EC were analyzed using a DRI carbon analyzer (model 2001, USA). Another piece of the filter sample ( $\left.8.6 \mathrm{~cm}^{2}\right)$ was extracted with Milli-Q water $(18.2 \mathrm{M} \Omega)$ and filtered through a PTFE syringe filter. Then the water extract was analyzed for water-soluble inorganic ions $\left(\mathrm{SO}_{4}^{2-}\right.$,
$\mathrm{NO}_{3}^{-}, \mathrm{NH}_{4}^{+}, \mathrm{Cl}^{-}, \mathrm{F}^{-}, \mathrm{Ca}^{2+}, \mathrm{K}^{+}, \mathrm{Na}^{+}$and $\left.\mathrm{Mg}^{2+}\right)$ using a Metrohm ion chromatographer (Metrohm 940, Switzerland) and WSOC using a Shimadzu TOC analyzer (TOC-L CPH, Japan) and concentrations of individual molecules, including levoglucosan, parent polycyclic aromatic hydrocarbons (PAHs), oxygenated PAHs (OPAHs), nitrophenols, isoprene, and $\alpha$ - and $\beta$-pinene-derived products, were measured using a gas chromatographer-electron-impact-ionization mass spectrometer (GC-EIMS, Agilent 7890A-5975C, USA) calibrated by authentic standards. More details on these measurements can be found in previous publications ( $\mathrm{Li}$ et al., 2014).

\subsection{Data interpretation}

In this study, water-insoluble OC (WIOC) was calculated by the difference between OC and WSOC:

$M_{\mathrm{WIOC}}=M_{\mathrm{OC}}-M_{\mathrm{WSOC}}$,

where $M_{\mathrm{WIOC}}, M_{\mathrm{OC}}$ and $M_{\mathrm{WSOC}}$ correspond to the mass concentration $\left(\mu \mathrm{gC} \mathrm{m}{ }^{-3}\right)$ of WIOC, OC and WSOC, respectively, in the air.

The absorption coefficient of WS-BrC ( $\mathrm{Abs}_{\lambda}$,WS-BrC, $\left.\mathrm{Mm}^{-1}\right)$ or WI-BrC $\left(\mathrm{Abs}_{\lambda}, \mathrm{WI}-\mathrm{BrC}, \mathrm{Mm}^{-1}\right)$ at a given wavelength $(\lambda)$ is determined from the UV-vis spectrum of the 
water extract (Hecobian et al., 2010; Laskin et al., 2015):

$\operatorname{Abs}_{\lambda}=\left(A_{\lambda}-A_{700}\right) \times \frac{V_{\text {solvent }}}{V_{\mathrm{a}} \times l} \times \ln (10) \times 100$,

where $A_{\lambda}$ is the absorbance of the water $\left(A_{\lambda}\right.$,WS-BrC $)$ or $\mathrm{ACN}\left(A_{\lambda, \mathrm{WI}-\mathrm{BrC}}\right)$ extract at $\lambda$, which is corrected for the field blank. $V_{\text {solvent }}(\mathrm{mL})$ is the volume of solvent (water or $\mathrm{ACN})$ used to extract the filter $(8 \mathrm{~mL})$ and $V_{\mathrm{a}}\left(\mathrm{m}^{3}\right)$ is the air volume passed through the filter punch. $l(\mathrm{~cm})$ is the optical length of the quartz cuvettes used for UV-vis measurement, and $\ln (10)$ is used to convert the logbase-10 (provided by the spectrophotometer) to natural logarithm. The value 100 is for unit conversion. A700 (absorbance at the wavelength of $700 \mathrm{~nm}$ ) is subtracted to minimize the interference of baseline shift. The mass absorption coefficient of WS-BrC $\left(\mathrm{MAC}_{\lambda, \mathrm{WS}-\mathrm{BrC}}, \mathrm{m}^{2} \mathrm{~g}^{-1}\right)$ or WI-BrC $\left(\mathrm{MAC}_{\lambda, \mathrm{WI}-\mathrm{BrC}}, \mathrm{m}^{2} \mathrm{~g}^{-1}\right)$ at the wavelength of $\lambda$ is calculated using Eq. (3):

$\mathrm{MAC}_{\lambda}=\frac{\mathrm{Abs}_{\lambda}}{M}$,

where $M$ is the mass concentration of WSOC or WIOC. Note that since it is possible that not all the WI-BrC was extracted into $\mathrm{ACN}$, the $\mathrm{Abs}_{\lambda, \mathrm{WI}-\mathrm{BrC}}$ (estimated uncertainty is $32 \%$ ) and $\mathrm{MAC}_{\lambda, \mathrm{WI}-\mathrm{BrC}}$ (estimated uncertainty is $33 \%$ ) reported in this study are likely the lower-bound values. Nevertheless, the underestimation is probably insignificant since Chen and Bond (2010) reported that $>92 \%$ of $\mathrm{BrC}$ was extractable by organic solvents (methanol or acetone).

The wavelength dependence for $\mathrm{BrC}$ absorption is fit with a power-law equation:

$\operatorname{Abs}_{\lambda}=K \times \lambda^{-\mathrm{AAE}}$,

where $K$ is a constant and AAE stands for absorption Ångström exponent. In this study, the AAE for a given sample is calculated through the linear regression of $\log \left(\mathrm{Abs}_{\lambda}\right)$ against $\log \lambda$ between 300 and $450 \mathrm{~nm}$. This wavelength range is chosen because the fits of all the samples in this study are better than $r^{2}=0.99$. Note that slightly higher AAE values (by up to $10 \%$ ) are obtained using a wider wavelength range (e.g., 300-550 nm; Fig. S2).

The fraction of solar irradiance absorbed by particulate $\mathrm{BrC}$ at a given wavelength $\lambda$ is estimated following the BeerLambert law:

$\frac{I_{0}-I}{I_{0}}(\lambda)=1-e^{-b_{\mathrm{ap}, \lambda, x} \times h_{\mathrm{ABL}}}$,

where $x$ denotes WS-BrC or WI-BrC, and $h_{\mathrm{ABL}}$ is the atmospheric boundary layer height (assuming $1200 \mathrm{~m}$ in summer and $600 \mathrm{~m}$ in winter) according to the assumption that the ground measurement results are representative of the average values in the whole planetary boundary layer (PBL) (Kirchstetter et al., 2004; Kirillova et al., 2014a). $I_{0}$ denotes the incident solar radiance in the form of either actinic flux (quanta $\mathrm{s}^{-1} \mathrm{~cm}^{-2} \mathrm{~nm}^{-1}$ ) or irradiance $\left(\mathrm{W} \mathrm{m}^{-2} \mathrm{~nm}^{-1}\right.$ ), which were obtained using the Quick TUV Calculator (http://cprm. acom.ucar.edu/Models/TUV/Interactive_TUV/, last access: 19 March 2019). $\left(I_{0}-I\right)$ denotes the direct absorption of solar actinic flux or irradiance by $\mathrm{BrC} . b_{\mathrm{ap}, \lambda, x}$ corresponds to the absorption coefficient $\left(b_{\mathrm{ap}}, \mathrm{m}^{-1}\right)$ of WS-BrC or WI$\mathrm{BrC}$ at a wavelength of $\lambda$. The absorption properties of $\mathrm{BrC}$ extracted by bulk solution may not entirely reflect the light absorption by ambient aerosols. However, an estimated conversion factor can be calculated from the light absorption of size-resolved samples using the Mie theory. Assuming that particles are of spherical morphology and externally mixed with other light-absorbing components, an imaginary refractive index ( $k$, responsible for absorption) could be obtained from MAC using the following equation (Laskin et al., 2015):

$k_{(\lambda)}=\frac{\rho \times \lambda \times \mathrm{Abs}_{\lambda}}{4 \pi \times M_{\mathrm{WSOC}}}=\frac{\rho \times \lambda \times \mathrm{MAC}_{\lambda}}{4 \pi}$,

where $\rho\left(\mathrm{g} \mathrm{cm}^{-3}\right)$ was particle density and assigned as 1.5 , and more details about Mie theory calculations can be found in the study by Liu et al. (2013). Previous studies showed that the light absorption coefficient of particulate $\mathrm{BrC}\left(b_{\mathrm{ap}, \lambda, \mathrm{BrC}}\right)$ is around $0.7-2.0$ times that from bulk solution (Abs $\lambda$,WS-BrC or WI-BrC ) (Liu et al., 2013; Sun et al., 2007). Here, a conversion factor of 1.3 is applied based on a Mie theory calculation of aerosols in Xi' an ( $\sim 40 \mathrm{~km}$ away from the sampling site) (Wu, 2018).

\section{Results and discussion}

\subsection{Optical absorption characteristics of WS-BrC and WI-BrC}

The average absorption spectra of WS-BrC and WI-BrC $(\lambda=300-700 \mathrm{~nm})$ during daytime and nighttime in different seasons are shown in Fig. 2a, b. The absorption Ångström exponents for both WS-BrC (AAE $\left.E_{W S-B r C}\right)$ and WI-BrC (AAE $\left.{ }_{W I-B r C}\right)$ are generally higher than 5, verifying the contribution of $\mathrm{BrC}$ to aerosol absorptivity in the region. The average $\mathrm{AAE}_{\mathrm{WS}-\mathrm{BrC}}$ values are similar between summer $(5.43 \pm 0.41)$ and winter $(5.11 \pm 0.53)$. Huang et al. (2014)

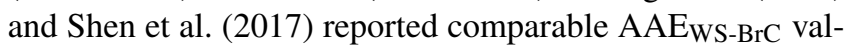
ues (5.3-5.7) with no significant seasonal change at urban sites in $\mathrm{Xi}$ ' an, suggesting common characteristics of $\mathrm{BrC}$ on a regional scale in the Guanzhong Basin of China. These results are comparable with the data reported in Guangzhou (5.3) (Liu et al., 2018), but much lower than those in Beijing (5.3-7.3) (Cheng et al., 2011; Yan et al., 2015b; Du et al., 2014) and Nanjing (6.7-7.3) (Chen et al., 2018). Moreover, comparable AAE values were reported for WS-BrC in Switzerland (3.8-5.1) (Moschos et al., 2018) and Nepal (4.2-5.6) (Wu et al., 2019; Kirillova et al., 2016), but higher AAE $E_{W S-B r C}$ values were found in the southeastern US $(7 \pm 1)$ 

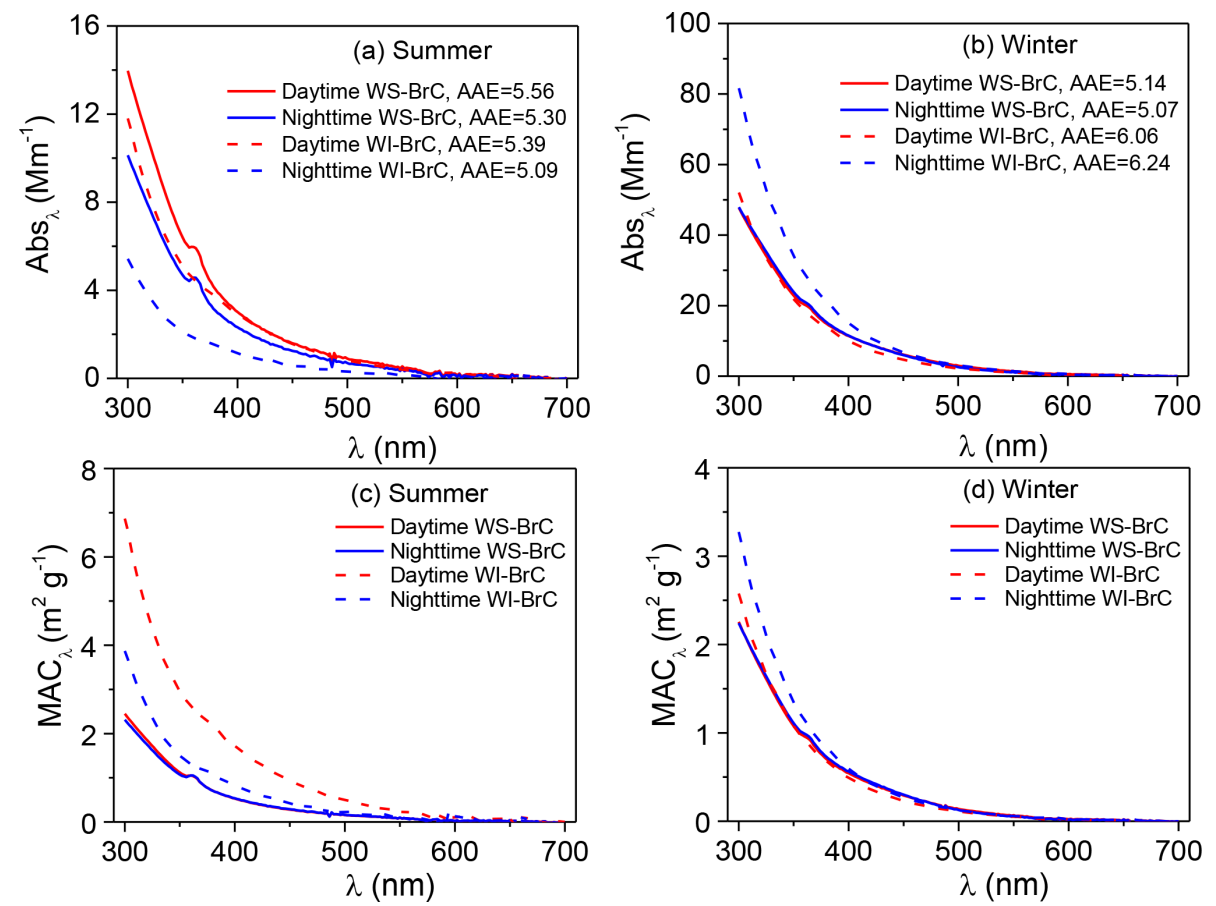

Figure 2. Average spectra of absorption coefficient $\left(\mathrm{Abs}_{\lambda}\right)(\mathbf{a}, \mathbf{b})$ and mass absorption coefficient $\left(\mathrm{MAC}_{\lambda}\right)(\mathbf{c}, \mathbf{d})$ of water-soluble $(\mathrm{WS}-\mathrm{BrC})$ and water-insoluble (WI-BrC) BrC during daytime and nighttime of summer and winter. Absorption Ångström exponent (AAE) is calculated by a linear regression of $\log \mathrm{Abs}_{\lambda}$ versus $\log \lambda$ in the wavelength range of $300-450 \mathrm{~nm}$.

(Hecobian et al., 2010), Los Angeles Basin (7.6 \pm 0.5$)$ (Zhang et al., 2013) and South Korea (5.84-9.17) (Kim et al., 2016).

The AAE $E_{W I-B r C}$ shows more obvious seasonal variations with a higher average value in winter $(6.04 \pm 0.22)$ than in summer $(5.01 \pm 0.58)$. This difference suggests that the chemical composition of WI-BrC might be more different in different seasons, due to variations in the sources and atmospheric formation and aging processes of light-absorbing hydrophobic compounds.

The light absorption properties of WS-BrC and WI$\mathrm{BrC}$ present obvious seasonal variations (Fig. 2). The average $( \pm 1 \sigma)$ Abs and MAC values of $\mathrm{BrC}$ at $365 \mathrm{~nm}$ (i.e., $\mathrm{Abs}_{365}$,Ws-BrC, $\mathrm{Abs}_{365}$,WI-BrC, $\mathrm{MAC}_{365}$,WS-BrC and $\mathrm{MAC}_{365 \text {,WI-BrC }}$ ) during daytime and nighttime in winter and summer are summarized in Table 1 . The value $365 \mathrm{~nm}$ was chosen to avoid interferences from inorganic compounds (e.g., nitrate and nitrite) and to be consistent with previous studies (Hecobian et al., 2010; Huang et al., 2018). On average, $\mathrm{Abs}_{365}$, WS-BrC is significantly higher than $\mathrm{Abs}_{365}$, WI-BrC in summer $\left(5.00 \pm 1.28 \mathrm{Mm}^{-1}\right.$ vs. $\left.2.95 \pm 1.94 \mathrm{Mm}^{-1}\right)$, but the values vary slightly in winter $\left(19.6 \pm 8.3 \mathrm{Mm}^{-1}\right.$ vs. $21.9 \pm 13.5 \mathrm{Mm}^{-1}$ ). The substantially higher BrC absorptions in winter correspond to a much higher organic aerosol concentration - WSOC and WIOC concentrations in winter are on average 4.2 and 14 times the concentrations in summer (Table 1). Elevated OA (organic aerosol) concentration during winter is due to a combination of lower PBL height and enhanced primary emissions (e.g., from residential heating) in the cold season. It is worth noting that the wavelength-dependent Abs of WS-BrC shows a minor tip at about $360 \mathrm{~nm}$ in both seasons (Fig. 2), which may be related to the contribution of some specific chromophores. For example, Lin et al. (2015) reported that some nitrogencontaining organic compounds (such as picric acid or nitrophenol) have a maximum absorption at a wavelength of $\sim 360 \mathrm{~nm}$. The tip possibly caused an overestimation of average Abs and MAC at a wavelength of $365 \mathrm{~nm}$ in this study. However, the influence seems insignificant based on a comparison of average Abs and MAC at wavelengths of 340, 350, 360, 370 and $380 \mathrm{~nm}$ (Table S1 in the Supplement).

The MACs of WS-BrC are comparable between the two seasons (Fig. 2c, d), with the average $\mathrm{MAC}_{365}$, ws-BrC being $1.00( \pm 0.18) \mathrm{m}^{2} \mathrm{~g}^{-1}$ in summer and $0.93( \pm 0.25) \mathrm{m}^{2} \mathrm{~g}^{-1}$ in winter (Table 1). As summarized in Table 2, the

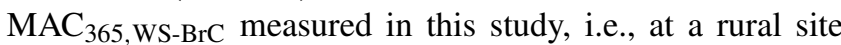
in the Guanzhong Basin of China, is comparable to or lower than the values observed in Asian cities such Xi' an (Huang et al., 2018), Beijing (Cheng et al., 2011), Seoul (Kim et al., 2016) and New Delhi (Kirillova et al., 2014b) but obviously higher than those at the regional sites in the North China Plain (Teich et al., 2017) and the background site on the Tibetan Plateau (Xu et al., 2020). Moreover, significantly lower

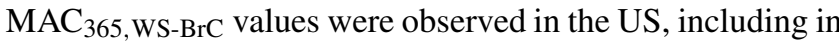


Table 1. Average $( \pm 1 \sigma)$ values $\mathrm{Abs}_{365}, \mathrm{MAC}_{365}$ and AAE of WS-BrC and WI-BrC, as well as concentrations of OC, WSOC, WIOC and measured organic species in the $\mathrm{PM}_{2.5}$ aerosols from the rural site in the Guanzhong Basin.

\begin{tabular}{|c|c|c|c|c|c|c|}
\hline & \multicolumn{3}{|c|}{ Summer } & \multicolumn{3}{|c|}{ Winter } \\
\hline & Average & Daytime & Nighttime & Average & Daytime & Nighttime \\
\hline $\mathrm{Abs}_{365, \mathrm{WS}-\mathrm{BrC}}\left(\mathrm{Mm}^{-1}\right)$ & $5.00 \pm 1.28$ & $5.64 \pm 1.34$ & $4.37 \pm 0.83$ & $19.6 \pm 8.3$ & $19.2 \pm 6.8$ & $19.9 \pm 9.5$ \\
\hline 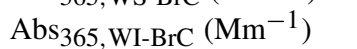 & $2.95 \pm 1.94$ & $4.23 \pm 1.93$ & $1.67 \pm 0.72$ & $21.9 \pm 13.5$ & $17.2 \pm 8.2$ & $26.7 \pm 15.8$ \\
\hline $\operatorname{MAC}_{365, \text { WS-BrC }}\left(\mathrm{m}^{2} \mathrm{~g}^{-1}\right)$ & $1.00 \pm 0.18$ & $0.99 \pm 0.17$ & $1.01 \pm 0.18$ & $0.93 \pm 0.25$ & $0.92 \pm 0.21$ & $0.94 \pm 0.28$ \\
\hline $\operatorname{MAC}_{365, \mathrm{WI}-\mathrm{BrC}}\left(\mathrm{m}^{2} \mathrm{~g}^{-1}\right)$ & $1.82 \pm 1.06$ & $2.45 \pm 1.14$ & $1.18 \pm 0.36$ & $0.95 \pm 0.32$ & $0.85 \pm 0.34$ & $1.05 \pm 0.28$ \\
\hline $\mathrm{AAE}_{\mathrm{WS}-\mathrm{BrC}}$ & $5.43 \pm 0.41$ & $5.56 \pm 0.4$ & $5.30 \pm 0.38$ & $5.11 \pm 0.53$ & $5.14 \pm 0.2$ & $5.07 \pm 0.72$ \\
\hline $\mathrm{AAE}_{W I-B r C}$ & $5.01 \pm 0.58$ & $4.74 \pm 0.19$ & $5.28 \pm 0.71$ & $6.04 \pm 0.22$ & $5.94 \pm 0.12$ & $6.15 \pm 0.24$ \\
\hline $\mathrm{OC}\left(\mu \mathrm{g} \mathrm{m}^{-3}\right)$ & $6.78 \pm 1.77$ & $7.74 \pm 1.73$ & $5.83 \pm 1.19$ & $45.9 \pm 22.9$ & $44.0 \pm 17.2$ & $47.9 \pm 27.2$ \\
\hline WSOC $\left(\mu \mathrm{g} \mathrm{m}^{-3}\right)$ & $5.06 \pm 1.11$ & $5.72 \pm 1.02$ & $4.39 \pm 0.72$ & $21.9 \pm 9.3$ & $22.1 \pm 8.0$ & $21.7 \pm 10.4$ \\
\hline WIOC $\left(\mu \mathrm{g} \mathrm{m}^{-3}\right)$ & $1.73 \pm 0.87$ & $2.02 \pm 1.04$ & $1.44 \pm 0.53$ & $24.0 \pm 14.3$ & $21.9 \pm 10.1$ & $26.2 \pm 17.3$ \\
\hline WSOC / OC & $0.75 \pm 0.07$ & $0.75 \pm 0.09$ & $0.76 \pm 0.04$ & $0.50 \pm 0.09$ & $0.51 \pm 0.08$ & $0.48 \pm 0.10$ \\
\hline Parent PAHs ( $\mathrm{ng} \mathrm{m}^{-3}$ ) & $8.81 \pm 5.09$ & $11.6 \pm 5.7$ & $5.98 \pm 1.9$ & $82.3 \pm 53.7$ & $70.8 \pm 35.4$ & $93.9 \pm 65.1$ \\
\hline OPAHs $\left(\mathrm{ng} \mathrm{m}^{-3}\right)$ & $14.0 \pm 14.0$ & $23.0 \pm 15.1$ & $4.97 \pm 1.34$ & $98.3 \pm 59.5$ & $89.4 \pm 39.8$ & $107 \pm 73$ \\
\hline Nitrophenols $\left(\mathrm{ng} \mathrm{m}^{-3}\right)$ & $0.94 \pm 0.26$ & $0.87 \pm 0.26$ & $1.02 \pm 0.24$ & $72.6 \pm 63.7$ & $41.1 \pm 15.5$ & $104 \pm 77$ \\
\hline $\mathrm{SOA}_{\mathrm{j}}^{\mathrm{a}}\left(\mathrm{ng} \mathrm{m}^{-3}\right)$ & $18.6 \pm 9.7$ & $15.0 \pm 8.0$ & $22.1 \pm 9.8$ & $\mathrm{BDL}^{\mathrm{c}}$ & BDL & BDL \\
\hline $\operatorname{SOA}_{\mathrm{p}}^{b}\left(\mathrm{ng} \mathrm{m}^{-3}\right)$ & $22.0 \pm 6.7$ & $25.2 \pm 6.7$ & $18.9 \pm 5.0$ & $\mathrm{BDL}$ & BDL & BDL \\
\hline Levoglucosan $\left(\mathrm{ng} \mathrm{m}^{-3}\right)$ & $98.7 \pm 83.7$ & $142 \pm 89$ & $55.1 \pm 48.7$ & $601 \pm 301$ & $569 \pm 138$ & $633 \pm 401$ \\
\hline
\end{tabular}

${ }^{\text {a }} \mathrm{SOA}_{\mathrm{i}}$ : tracers of SOA formed from isoprene (SOAi) oxidation, i.e., the sum of 2-methylglyceric acid, 2-methylthreitol and 2-methylerythritol. ${ }^{\text {b }} \mathrm{SOA}_{\mathrm{i}}$ : tracers of SOA formed from $\alpha$ - and $\beta$-pinene (SOAp) oxidation, i.e., the sum of pinonic acid, pinic acid and 3-methyl-1,2,3-butanetricarboxylic acid. ${ }^{\mathrm{c}}$ BDL: below detection limit $\left(<0.17 \mathrm{ng} \mathrm{m}^{-3}\right)$.

the Los Angeles Basin (Zhang et al., 2013), the southeastern US (Hecobian et al., 2010) and Atlanta (Liu et al., 2013).

In winter, the average $\mathrm{MAC}_{365 \text {,WI-BrC }}\left(0.95 \pm 0.32 \mathrm{~m}^{2} \mathrm{~g}^{-1}\right)$ is comparable to $\mathrm{MAC}_{365 \text {, Ws-BrC }}\left(0.93 \pm 0.25 \mathrm{~m}^{2} \mathrm{~g}^{-1}\right.$; Table 1). However, in summer the $\mathrm{MAC}_{365}$,WI-BrC is much higher than $\mathrm{MAC}_{365 \text {, WS-BrC }}(1.82 \pm 1.06$ vs. $1.00 \pm$ $0.18 \mathrm{~m}^{2} \mathrm{~g}^{-1}$ ), indicating a relatively stronger light absorption capability of hydrophobic chromophores than hydrophilic chromophores. Further, the fact that the summertime $\mathrm{MAC}_{365}$,WI-BrC is nearly double the wintertime $\mathrm{MAC}_{365 \text {,WI-BrC }}$ suggests that more light-absorbing molecules are formed in the warm season.

Figure 2 compares the wavelength-dependent light absorptivity (i.e., $\mathrm{Abs}_{\lambda}$ and $\mathrm{MAC}_{\lambda}$ ) of WS-BrC and WI$\mathrm{BrC}$ between day and night in summer and winter. Higher $\mathrm{Abs}_{\lambda}$,WS-BrC and $\mathrm{Abs}_{\lambda, \mathrm{WI}-\mathrm{BrC}}$ occurred during daytime in summer but during nighttime in winter. The $\mathrm{MAC}_{\lambda}$ values of WS-BrC are overall similar between daytime and nighttime in both seasons. However, the $\mathrm{MAC}_{\lambda}$ values of WI$\mathrm{BrC}$ show a significant daytime increase in summer over the whole wavelength range of 300-700 nm (Fig. 2c). The daynight change of $\mathrm{BrC}$ light absorptivity can be viewed more obviously in Fig. 1e and $\mathrm{f}$, where the temporal variations in the $\mathrm{Abs}_{365}$ and $\mathrm{MAC}_{365}$ of WS-BrC and WI-BrC during summer 2016 (3-23 August) and winter 2017 (20 January1 February) are presented. The highest day / night ratio of

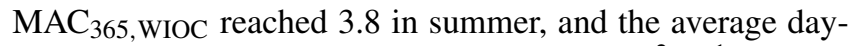
time $\mathrm{MAC}_{365}$,WI-BrC in summer $\left(2.45 \pm 1.14 \mathrm{~m}^{2} \mathrm{~g}^{-1}\right)$ is more than twice the value during nighttime $\left(1.18 \pm 0.36 \mathrm{~m}^{2} \mathrm{~g}^{-1}\right.$; Table 1). A possible reason for this observation is that there are additional sources of WI-BrC during summer daytime in this rural region, such as secondary formation of hydrophobic light-absorbing compounds.

Figures 3 and 4 present the cross correlations of $\mathrm{Abs}_{365}$,WS-BrC and Abs 365 ,WI-BrC with major chemical components (e.g., WSOC, WIOC and sulfate) and molecular tracer species in summer and winter. In winter, $\mathrm{Abs}_{365}$,WS-BrC correlates strongly with WSOC concentration $\left(r^{2}=0.80\right)$, as does $\mathrm{Abs}_{365}$,WI-BrC with WIOC $\left(r^{2}=0.76\right)$. However, their relationships in summer are much weaker, especially for the correlation between $\mathrm{Abs}_{365}$,WI-BrC and WIOC $\left(r^{2}=0.50\right)$. Considering that secondary OA (SOA) is mainly comprised of water-soluble compounds, such as polyalcohols or polyacids and phenols (Kondo et al., 2007), the much higher WSOC / OC ratio in summer $(0.75 \pm 0.07)$ compared to winter $(0.50 \pm 0.09)$ confirms more prevalent SOA formation in summer associated with higher temperature and stronger solar radiation. Formation of secondary organic chromophores may lead to a more complex composition of $\mathrm{BrC}$ in summer. More evidences on secondary $\mathrm{BrC}$ formation is provided in the subsequent sections.

Numerous studies reported that biomass burning is a dominant source of $\mathrm{BrC}$ in the atmosphere (Desyaterik et al., 2013; Washenfelder et al., 2015). In the current study, levoglucosan - a key tracer for biomass burning emissions ( $\mathrm{Si}$ moneit, 2002) - was determined. As shown in Figs. 3 and 
4, levoglucosan correlates well with WSOC and WIOC in both summer and winter $\left(r^{2}=0.45-0.77\right)$, suggesting that biomass burning is an important source of OA in the rural region of Guanzhong Basin. For most of the periods in this study, the $\mathrm{MAC}_{365}$, wS-BrC and $\mathrm{MAC}_{365}$, wI-BrC values are within the range of MAC of biomass burning aerosols (e.g., 1.3-1.8 for corn stalk (Li et al., 2016a), $\sim 1.37$ for rice straw (Park and $\mathrm{Yu}, 2016$ ) and $\sim 1.9$ for biomass burning (BB) smoke particles (Lin et al., 2017). Also, Abs 365 ,WI-BrC values in both summer and winter correlate well with levoglucosan $\left(r^{2}=0.74\right.$ and 0.62 , respectively), demonstrating an important contribution of biomass burning to WI-BrC despite the fact that levoglucosan itself is water soluble. The relationships between the Abs 365 ,WS-BrC and levoglucosan are much weaker $\left(r^{2}=0.40\right.$ and 0.45 in summer and winter, respectively), suggesting more complex sources of WS-BrC in the region.

\subsection{Molecular characterization of $\mathrm{BrC}$ aerosols}

Five categories of molecular tracer compounds, i.e., parentpolycyclic aromatic hydrocarbons (parent PAHs), oxygenated PAHs (OPAHs), nitrophenols, isoprene-derived products $\left(\mathrm{SOA}_{\mathrm{i}}\right)$ and $\alpha$ - and $\beta$-pinene-derived products $\left(\mathrm{SOA}_{\mathrm{p}}\right)$, were determined by the GC-EIMS technique to investigate the formation pathways of $\mathrm{BrC}$ in this study. Their average concentrations as well as daytime and nighttime differences are summarized in Table 1, and the temporal variation profiles of the sum concentrations of each category, together with levoglucosan time series, are presented in Fig. S3.

PAHs and their oxidized products are important $\mathrm{BrC}$ chromophores, since the large conjugated polycyclic structures are strongly light-absorbing in the near-UV range (Samburova et al., 2016; Huang et al., 2018). A total of 14 parent PAHs and 5 OPAHs (Table S2) were determined in this study. Parent PAHs are unsubstituted PAHs mainly emitted directly from incomplete combustion of coal, biofuel, gasoline or other materials, whereas OPAHs can be emitted directly from combustion sources or formed from photochemical oxidation of the parent PAHs. The time trends of parent PAHs and OPAHs are highly similar in both seasons $\left(r^{2}=0.90\right.$ and 0.98 in summer and winter, respectively; Figs. 3 and 4), suggesting that they have common combustion sources. In addition, both parent PAHs and OPAHs presented good correlations with levoglucosan, particularly in winter ( $r^{2}=0.69$ and 0.73 , respectively; Fig. 4$)$, indicating that biomass burning is an important contributor to ambient particulate PAHs in the region. PAHs, as well as levoglucosan, are elevated during nighttime in winter, corresponding to enhanced biomass burning emissions from heating-related activities as well as reduced boundary layer height at night. In contrast, the average daytime concentrations of parent PAHs $\left(11.6 \pm 5.7 \mathrm{ng} \mathrm{m}^{-3}\right)$ and levoglucosan $\left(142 \pm 89 \mathrm{ng} \mathrm{m}^{-3}\right)$ in summer are respectively about 1.95 and 2.58 times the values at night (Table 1). The daytime enhancement of OPAH concentrations in summer is even more pronounced with an average day / night ratio of $\sim 4.6$ and as high as 9.8 for individual OPAH species (e.g., 6H-henzo(cd)pyrene-6-one; Fig. S4). Both parent PAHs and OPAHs, which are hydrophobic and thus mainly exist as WIOC, demonstrate a good linear relationship with $\mathrm{Abs}_{365}$,WI-BrC in both winter and summer $\left(r^{2}=0.49-0.83\right.$; Figs. 3 and 4). However, the good correlation between OPAHs and $\mathrm{Abs}_{365}$, WI-BrC in summer appears to be mainly driven by daytime production, as the correlation coefficient $\left(r^{2}\right)$ is 0.72 for the daytime data but is $<0.1$ for the nighttime data (Fig. S5a). These results suggest that photochemical formation of light absorption compounds is an important source of $\mathrm{BrC}$ during summer in the Guanzhong Basin.

We estimated the potential contribution of parent PAHs and OPAHs to the light absorption of WI-BrC using a method reported in Samburova et al. (2016). Details on the method are presented in the Supplement. Table S3 summarizes the solar-spectrum-weighed mass absorption coefficients for PAHs $\left(\mathrm{MAC}_{\mathrm{PAH}, \mathrm{av}}\right)$ used in the calculation. As shown in Fig. 5, the contribution of parent PAHs to solar-spectrumweighed absorption coefficient of WI-BrC varies between $0.55 \%$ and $0.66 \%$ with slight diurnal or season variations (Table S3). However, the contribution of OPAHs clearly shows higher daytime values, especially in summer. The average contribution of OPAHs to the solar-spectrum-weighed absorption coefficient of WI-BrC in summer is $0.51 \pm 0.28 \%$ during daytime and $0.34 \pm 0.19 \%$ during nighttime. These results indicate that more secondary water-insoluble aromatic chromophores were produced via photochemical oxidation during summertime in the rural region.

Nitrophenols were identified as one of the most important light-absorbing compounds in particles and cloud water influenced by BB emission in China (Desyaterik et al., 2013). These compounds can be either directly emitted from burning of biomass (Xie et al., 2019) or formed in the atmosphere through gas-phase and aqueous-phase reactions of aromatic precursors including benz $[a]$ pyrene ( $\mathrm{Lu}$ et al., 2011), naphthalene (Kitanovski et al., 2014), catechol and guaiacol (Ofner et al., 2011), and toluene (Liu et al., 2015) in the presence of $\mathrm{NO}_{x}$. In this study, only a few nitrophenol compounds were detected in PM (Table S2) and their average $( \pm 1 \sigma)$ concentration is $0.94( \pm 0.26) \mathrm{ng} \mathrm{m}^{-3}$ in summer and $72.6( \pm 63.7) \mathrm{ng} \mathrm{m}^{-3}$ in winter. The wintertime concentrations of nitrophenols measured in the current study are comparable to those detected in Shanghai (Li et al., 2016b), at Mt. Tai in Shandong Province of China (Desyaterik et al., 2013) and Ljubljana in Slovenia (Kitanovski et al., 2012), but the summertime concentrations observed are more comparable to those detected in the Los Angeles Basin in the US (Zhang et al., 2013). The substantially lower concentration of nitrophenols in summer may be related to rapid photodegradation in the atmosphere. Indeed, according to a laboratory study conducted by Zhao et al. (2015), the timescale 
Table 2. Comparison of $\mathrm{MAC}_{365}$,WS-BrC values in the present study and those reported in earlier studies in China, India and the United States (US).

\begin{tabular}{|c|c|c|c|c|}
\hline Sampling site & Sampling time & Season & $\begin{array}{r}\mathrm{MAC}_{365, \mathrm{WS}-\mathrm{BrC}} \\
\left(\mathrm{m}^{2} \mathrm{~g}^{-1}\right)\end{array}$ & Reference \\
\hline Lincun, Shaanxi, China & $\begin{array}{l}\text { 3-23 Aug } 2016 \\
\text { 20 Jan-1 Feb } 2017\end{array}$ & $\begin{array}{l}\text { Summer } \\
\text { Winter }\end{array}$ & $\begin{array}{l}1.00 \pm 0.18 \\
0.93 \pm 0.25\end{array}$ & This study \\
\hline Xi'an, China & $\begin{array}{l}1 \text { Jun-31 Aug } 2009 \\
15 \text { Nov 2008-14 Mar } 2009\end{array}$ & $\begin{array}{l}\text { Summer } \\
\text { Winter }\end{array}$ & $\begin{array}{l}0.98 \pm 0.21 \\
1.65 \pm 0.36\end{array}$ & Huang et al. (2018) \\
\hline Beijing, China & $\begin{array}{l}20 \text { Jun-20 Jul } 2009 \\
9 \text { Jan-12 Feb } 2009\end{array}$ & $\begin{array}{l}\text { Summer } \\
\text { Winter }\end{array}$ & $\begin{array}{l}1.8 \pm 0.2 \\
0.7 \pm 0.2\end{array}$ & Cheng et al. (2011) \\
\hline $\begin{array}{l}\text { Xianghe, Hebei, China } \\
\text { Wangdu, Hebei, China }\end{array}$ & $\begin{array}{l}\text { 9-14 Jul and 21 Jul-1 Aug } 2013 \\
\text { 4-24 Jun } 2014\end{array}$ & $\begin{array}{l}\text { Summer } \\
\text { Summer }\end{array}$ & $\begin{array}{l}0.38 \pm 0.52^{*} \\
0.55 \pm 0.15^{*}\end{array}$ & Teich et al. (2017) \\
\hline Mt. Waliguan, Qinghai, China & $1-31$ Jul 2017 & Summer & 0.48 & Xu et al. (2020) \\
\hline Seoul, South Korea & $\begin{array}{l}13 \text { Aug-9 Sep } 2013 \\
9 \text { Jan-8 Feb } 2013\end{array}$ & $\begin{array}{l}\text { Summer } \\
\text { Winter }\end{array}$ & $\begin{array}{l}0.28 \\
1.02\end{array}$ & Kim et al. (2016) \\
\hline New Delhi, India & 24 Oct 2010-25 Mar 2011 & Winter & $1.6 \pm 0.5$ & Kirillova et al. (2014b) \\
\hline Los Angeles Basin, US & mid-May-mid-June 2010 & Summer & 0.71 & Zhang et al. (2013) \\
\hline Southeastern US & 2007 & Annually & $0.3-0.7$ & Hecobian et al. (2010) \\
\hline Atlanta, US & 17 May-29 Sep 2012 & Summer and Fall & $0.14-0.53$ & Liu et al. (2013) \\
\hline
\end{tabular}

* Data at Xianghe and Wangdu were the averaged MAC of WSOC at a wavelength of $370 \mathrm{~nm}$ (i.e., MAC $370, \mathrm{WS}_{-\mathrm{BrC}}$ ).

for photobleaching of nitrophenols can be an hour or less. Furthermore, as shown in Fig. S5b, during wintertime, when low temperature and weak solar irradiation suppress the photodegradation process, nitrophenols' concentration anticorrelates with the $\mathrm{O}_{3}$ mixing ratio in a nonlinear manner $\left(r^{2}=\right.$ 0.60). On average, concentration of nitrophenols in winter is 2.5 times higher during nighttime than during daytime, whereas the nighttime concentrations of levoglucosan and PAHs are only slightly higher than the daytime concentrations (by $11 \%$ and $33 \%$, respectively; Table 1). Levoglucosan and PAHs are less photochemically reactive than nitrophenols. These results confirm that nitrophenols, and other photoreactive $\mathrm{BrC}$ compounds, may undergo significant atmospheric degradation during summertime.

Both summertime and wintertime $\mathrm{Abs}_{365}$,Ws-BrC correlated well with the concentrations of nitrophenols $\left(r^{2}=\right.$ 0.51-0.72, Fig. S5c, d), suggesting an important contribution of nitrated aromatic compounds to light absorption of WS-BrC in the study area. Using the MAC of individual nitrophenol reported in Zhang et al. (2013), we calculated that the contributions of nitrophenols to aerosol light absorption are 6.5-27 times higher than their mass contributions to WSOC and that the fractions are much higher in winter $(2.44 \pm 1.78 \%)$ than in summer $(0.12 \pm 0.03 \%$; Table S3). In addition, due to a significantly higher abundance of nitrophenols during nighttime in winter, their fractional contribu- tion to aerosol absorption is on average 2.5 times higher than during the day $(3.47 \pm 2.03 \%$ vs. $1.41 \pm 0.29 \%)$.

On a global scale, biogenic VOCs, mostly consisting of isoprene and monoterpenes, are nearly an order of magnitude more abundant than anthropogenic VOCs (Guenther et al., 2006), and their secondary products are estimated to be a predominant contributor to global SOA burden (Heald et al., 2008). Recent studies (Lin et al., 2014; Nakayama et al., 2012, 2015) showed that a large number of biogenic SOA compounds are light absorptive. Some tracers of SOA formed from isoprene $\left(\mathrm{SOA}_{\mathrm{i}}\right)$ and $\alpha$ - and $\beta$-pinene $\left(\mathrm{SOA}_{\mathrm{p}}\right)$ oxidation were measured in the summertime samples (Table S2), and their temporal variations are shown in Fig. S3. No biogenic SOA tracer species were detectable in the winter samples in this study. Similar results were obtained in our previous study at Mt. Hua in the Guanzhong Basin (Li, 2011). These findings are consistent with low emissions of biogenic VOCs and low oxidation rates in this region during cold seasons. The average concentrations of $\mathrm{SOA}_{i}$ and $\mathrm{SOA}_{\mathrm{p}}$ tracers in summer are $18.6 \pm 9.7$ and $22.0 \pm 6.7 \mathrm{ng} \mathrm{m}^{-3}$, respectively. Neither $\mathrm{SOA}_{i}$ tracers nor $\mathrm{SOA}_{\mathrm{p}}$ tracers showed significant correlations with the absorption coefficient of WSOC or WIOC, suggesting a low contribution of biogenic SOA to aerosol light absorption in the region. In addition, compared to the MAC values observed in this study, the MACs of biogenic SOA reported in literature are much lower, on average, by nearly an order of magnitude (Laskin 


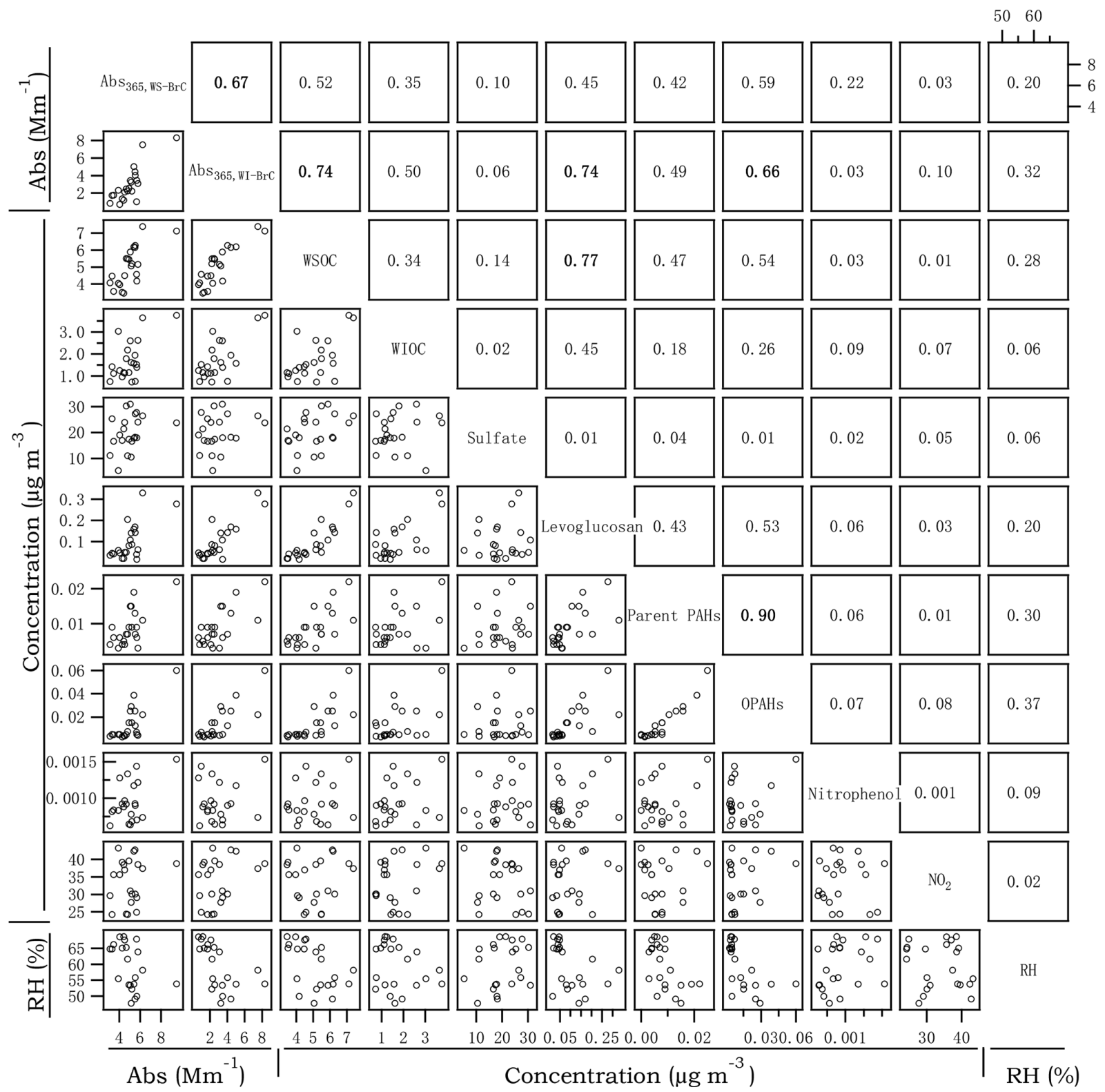

Figure 3. Cross correlations between $\mathrm{Abs} 365$, WS-BrC, Abs365, WI-BrC, selected chemical compositions and RH in summer. The numbers at the upper right denote the linear correlation coefficients $\left(r^{2}\right)$ of the corresponding scatter plots.

et al., 2015), which further supports an insignificant contribution of biogenic sources to $\mathrm{BrC}$ in this region. This finding is consistent with the fact that the Guanzhong Basin is a highly polluted region, where the major emission sources of organic aerosols are anthropogenic.

\subsection{Variation in $\mathrm{BrC}$ during extreme haze events in winter}

In recent years, extremely severe haze events with very high $\mathrm{PM}_{2.5}$ concentrations (up to $500-600 \mu \mathrm{g} \mathrm{m}^{-3}$ ) and low visibility (lower than $1 \mathrm{~km}$ ) occurred frequently during wintertime in China (Huang et al., 2014). In this study, a heavy haze event occurred during 21-26 January when $\mathrm{PM}_{2.5}$ concentration at the rural site increased continuously from $\sim 100$ to $430 \mu \mathrm{g} \mathrm{m}^{-3}$ and visibility decreased from $>10$ to $\sim 1.4 \mathrm{~km}$ (Fig. 1b, d). Similar to most haze events occurring in northeast China, this event was associated with stagnant meteorological conditions with low wind speed $\left(<1 \mathrm{~km} \mathrm{~s}^{-1}\right)$, which promote the accumulation of pollutants. In addition, secondary inorganic aerosol species, e.g., $\mathrm{SO}_{4}^{2-}, \mathrm{NO}_{3}^{-}$and $\mathrm{NH}_{4}^{+}$, increased sharply (Fig. 1d), which indicates secondary aerosol formation was enhanced during the haze event despite the low solar irradiance and low $\mathrm{O}_{3}$ concentration (e.g., $2--40 \mu \mathrm{g} \mathrm{m}^{-3}$; Fig. 1c). Recent studies by Wang et 


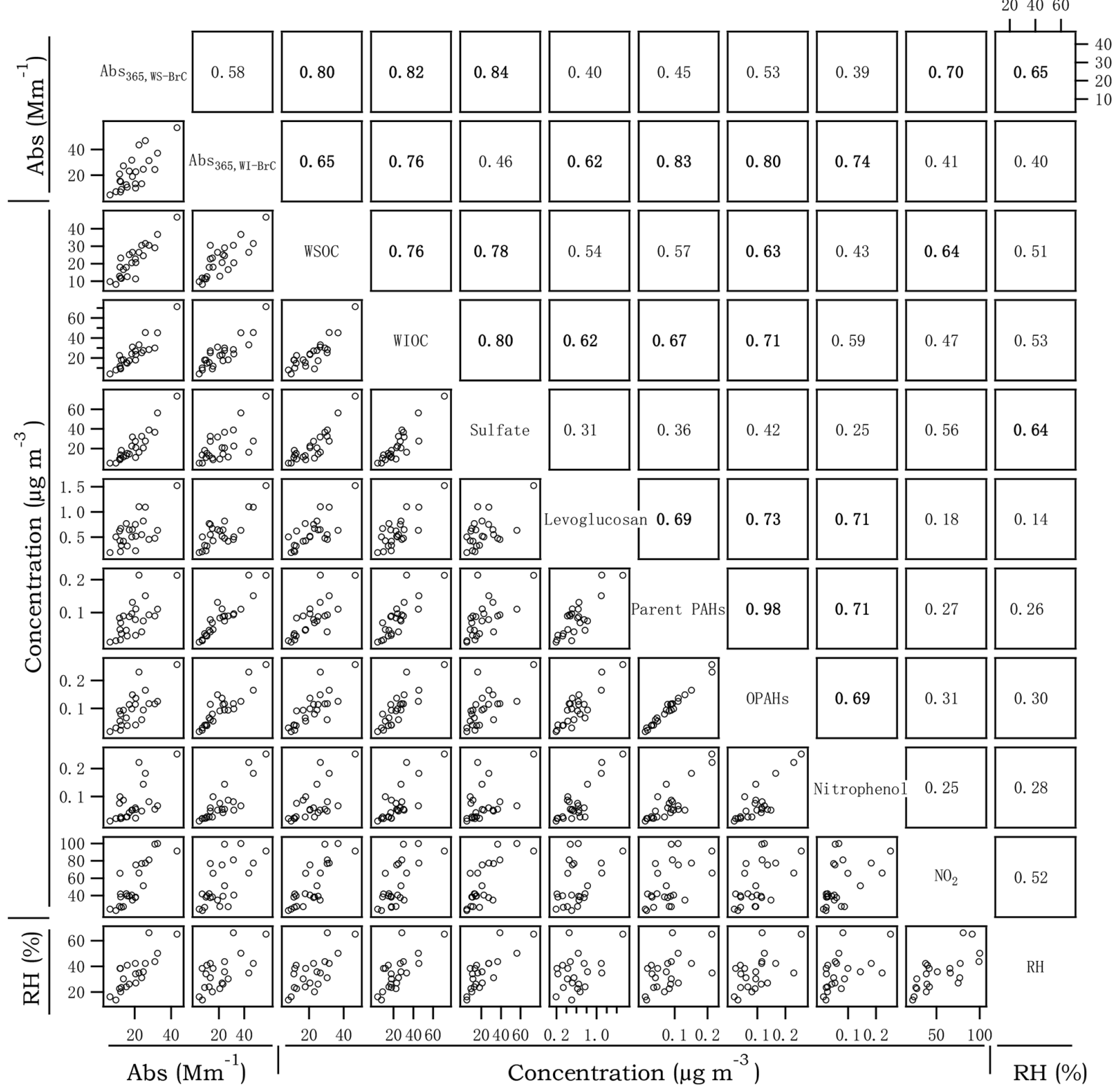

Figure 4. Cross correlations between $\mathrm{Abs}_{365}$, WS-BrC, $\mathrm{Abs}_{365}$, WI-BrC, selected chemical compositions and $\mathrm{RH}$ in winter. The numbers at the upper right denote the linear correlation coefficients $\left(r^{2}\right)$ of the corresponding scatter plots.

al. (2016) and Cheng et al. (2016) reported dramatic increases in secondary inorganic components, mainly sulfate, nitrate and ammonium (SNA), during haze periods in China and attributed the increases to enhanced aqueous reactions under high-relative-humidity (RH) conditions with $\mathrm{NO}_{2}$ being an important oxidant. Moreover, Huang et al. (2014) observed that SOA also increased noticeably during haze periods in winter. Indeed, as shown in Fig. 4, $\mathrm{SO}_{4}^{2-}$ correlates well with $\mathrm{RH}\left(r^{2}=0.64\right)$ and $\mathrm{NO}_{2}\left(r^{2}=0.56\right)$ in winter. In addition, Abs365,ws-BrC, which increases continuously during the haze period with a peak value at $43.3 \mathrm{Mm}^{-1}$ (Fig. 1e), correlates well with $\mathrm{RH}\left(r^{2}=0.65\right)$, sulfate $\left(r^{2}=0.84\right)$ and
$\mathrm{NO}_{2}\left(r^{2}=0.70\right)$ (Fig. 4). In contrast, Abs 365 ,WI-BrC presents obvious diurnal variation during the haze period, and the correlation of RH $\left(r^{2}=0.40\right)$, sulfate $\left(r^{2}=0.46\right)$ and $\mathrm{NO}_{2}$ $\left(r^{2}=0.41\right)$ with Abs365, WI-BrC is also much weaker than that with Abs365,Ws-BrC. These results suggest that aqueous oxidation played a role in the formation of WS-BrC (Laskin et al., 2015) during the haze period, although stagnant meteorological conditions with low wind speed can also promote its accumulation. This finding is consistent with our previous study conducted in Xi' an (Wu et al., 2020), which also found a secondary formation of $\mathrm{BrC}$ in winter by using stable carbon isotope composition analysis. In contrast, a slowly 

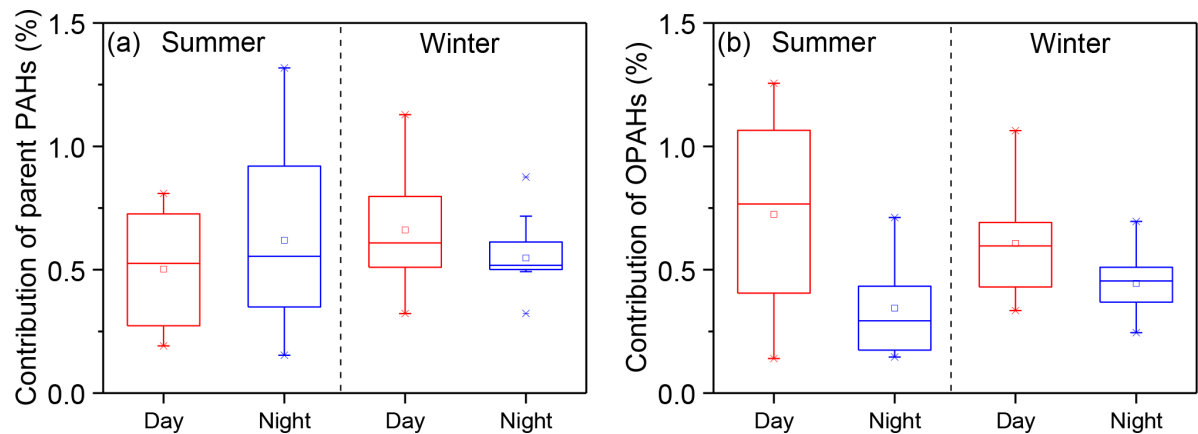

Figure 5. Average contribution of parent PAHs and OPAHs to the bulk light absorption of WI-BrC (300-700 nm) during daytime and nighttime of summer and winter.

Table 3. Average direct solar absorption of water-soluble and water-insoluble $\mathrm{BrC}$ during summer and winter.

\begin{tabular}{|c|c|c|c|c|}
\hline & \multicolumn{2}{|c|}{ WSOC } & \multicolumn{2}{|c|}{ WIOC } \\
\hline & Summer & Winter & Summer & Winter \\
\hline \multicolumn{5}{|c|}{ Actinic flux $\left(\times 10^{14}\right.$ quanta s $\left.{ }^{-1} \mathrm{~cm}^{-2}\right)$} \\
\hline $300-400 \mathrm{~nm}$ & $1.55 \pm 0.43$ & $2.14 \pm 0.92$ & $1.03 \pm 0.64$ & $2.53 \pm 1.52$ \\
\hline $400-700 \mathrm{~nm}$ & $1.77 \pm 0.6$ & $2.67 \pm 1.04$ & $1.24 \pm 0.8$ & $2.58 \pm 1.48$ \\
\hline \multicolumn{5}{|c|}{ Irradiance $\left(\mathrm{W} \mathrm{m}^{-2}\right)$} \\
\hline $300-400 \mathrm{~nm}$ & $0.51 \pm 0.14$ & $0.57 \pm 0.25$ & $0.34 \pm 0.21$ & $0.68 \pm 0.41$ \\
\hline $400-700 \mathrm{~nm}$ & $0.49 \pm 0.17$ & $0.57 \pm 0.22$ & $0.35 \pm 0.23$ & $0.55 \pm 0.32$ \\
\hline \multicolumn{5}{|c|}{ Relative to EC (\%) } \\
\hline $300-400 \mathrm{~nm}$ & $49.4 \pm 14.5$ & $25.9 \pm 5.47$ & $29.4 \pm 11.0$ & $29.0 \pm 10.4$ \\
\hline $400-700 \mathrm{~nm}$ & $10.0 \pm 3.52$ & $4.99 \pm 1.23$ & $6.19 \pm 2.42$ & $4.51 \pm 1.44$ \\
\hline
\end{tabular}

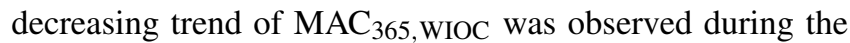
haze period, suggesting that some of the water-insoluble $\mathrm{BrC}$ species were oxidized to form water-soluble chromophores, possibly through aqueous-phase reactions.

It is worthwhile to mention that 27 January 2017 was the Chinese New Year's Eve and a large number of fireworks were set off for celebration. During this night, the concentrations of $\mathrm{PM}_{2.5}$, OC, EC, WSOC and WIOC as well as SNA were $25 \%-51 \%$ lower than their wintertime average concentrations due to the higher wind speed favoring atmospheric dispersion (Fig. 1). However, the $\mathrm{MAC}_{365}$, wS-BrC (1.81) increased to about 2 times its average value in winter, and $\mathrm{Abs}_{365}$,Ws-BrC $\left(20.5 \mathrm{Mm}^{-1}\right)$ also showed a slight increase. Meanwhile, metal ions, which are abundant in fireworks (Wu et al., 2018; Jiang et al., 2015), such as $\mathrm{K}^{+}, \mathrm{Mg}^{2+}$ and $\mathrm{Ca}^{2+}$, increased substantially during the night as well (Fig. S6). These results indicate that the in-

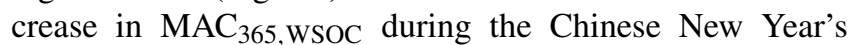
Eve is likely mainly contributed by metal-containing lightabsorbing compounds emitted from fireworks (Laskin et al., 2015; Tran et al., 2017).

\subsection{Estimation of direct absorption of solar radiation by BrC}

Since the light absorption of $\mathrm{BrC}$ is mainly in the UV spectral region, an important concern is that $\mathrm{BrC}$ can reduce the solar actinic flux and thus affect atmospheric photochemistry and tropospheric ozone production (Jacobson, 1998; Mohr et al., 2013). In this study, the direct absorptions of solar radiation by both WS-BrC and WI-BrC were estimated by using Eq. (7). Figure S7 presents the incident solar irradiance and actinic flux spectra determined for the region under midday summer (10 August 2016 at 13:00 Beijing (BJ) time, UTC+8) and winter (25 January 2017 at 13:00 BJ time) conditions. Note that the local time at Guanzhong is $\sim 1 \mathrm{~h}$ later than BJ time.

Table 3 presents a summary of the calculated direct solar absorptions of $\mathrm{BrC}$. In summer, the direct attenuation of actinic flux by WS-BrC and WI-BrC is estimated at $1.55 \times 10^{14} \pm 0.43 \times 10^{14}$ and $1.03 \times 10^{14} \pm 0.64 \times$ $10^{14}$ quanta s ${ }^{-1} \mathrm{~cm}^{-2}$, respectively, in the UV range (300$400 \mathrm{~nm}$ ), which accounts for $0.83 \pm 0.23 \%$ and $0.53 \pm 0.33 \%$, respectively, of the total down-welling radiation. In win- 
ter, the direct absorptions by $\mathrm{BrC}$ are higher, with WS-BrC and $\mathrm{WI}-\mathrm{BrC}$ on average accounting for $1.67 \pm 0.72 \%$ and $2.07 \pm 1.24 \%$, respectively, of the total down-welling radiation in the UV range. These results suggest that $\mathrm{BrC}$ may have a significant influence on atmospheric photochemistry in the UV range. In the visible spectral region (400$700 \mathrm{~nm}$ ), the contributions of WS-BrC and WI-BrC to the total down-welling radiation are negligible: $0.10 \pm 0.03 \%$ and $0.07 \pm 0.05 \%$ in summer and $0.15 \pm 0.06 \%$ and $0.15 \pm 0.08 \%$ in winter, respectively.

Another concern of $\mathrm{BrC}$ is that it can absorb solar irradiance to influence tropospheric temperature in a similar way as black carbon (BC) or elemental carbon (EC) (Feng et al., 2013; Laskin et al., 2015). In our study, the direct absorption of solar irradiance by WS-BrC and WI-BrC is estimated at $0.51 \pm 0.14$ and $0.34 \pm 0.21 \mathrm{~W} \mathrm{~m}^{-2}$ in summer and $0.57 \pm 0.25$ and $0.68 \pm 0.41 \mathrm{~W} \mathrm{~m}^{-2}$ in winter in the UV range. To evaluate the contribution of $\mathrm{BrC}$ to total aerosol absorption, we also estimated the direct absorption of EC based on the carbon analyzer data according to the method described by Kirillova et al. (2014b) and Kirchstetter and Thatcher (2012) (see Supplement). The estimated contributions of light absorption of $\mathrm{BrC}$ relative to $\mathrm{EC}$ are shown in Table 3. In the visible region, the contribution is estimated at $10.0 \pm 3.52 \%$ in summer and $4.99 \pm 1.23 \%$ in winter for WS-BrC and $6.19 \pm 2.42 \%$ and $4.51 \pm 1.44 \%$, respectively, for WI-BrC. However, in the UV range, the fractions increase to $49.3 \pm 14.5 \%$ in summer and $25.9 \pm 5.47 \%$ in winter for WS-BrC and $29.4 \pm 11.0 \%$ and $29.0 \pm 10.4 \%$ for WI-BrC, which are within the range of the values reported in other regions in China (Huang et al., 2018), India (Kirillova et al., 2014b) and South Korea (Kirillova et al., 2014a). On the other hand, the direct light absorption of WI-BrC represents a substantive contribution to that of total $\mathrm{BrC}$ in this study, which is about $40 \%$ in summer and more than $50 \%$ in winter in both the UV and visible ranges, emphasizing the important role that WI-BrC likely plays in atmospheric chemistry and the Earth's climate system, especially in China.

\section{Summary and conclusion}

Both WS-BrC and WI-BrC showed elevated Abs in winter (4-7 times higher than those in summer), corresponding to much higher concentrations of WSOC and WIOC due to a combination of lower PBL height and enhanced primary emissions (e.g., from residential heating) in the cold season. No significant differences were found for the daytime and nighttime MACs of WS-BrC in summer or for the MACs of WS-BrC and WI-BrC in winter. However, the average daytime $\mathrm{MAC}_{365}$,WI-BrC was more than twice the nighttime value in summer. We found that the average daytime concentrations of both parent PAHs and levoglucosan in summer were around 2 times the values at night, and the daytime OPAH concentration was more than 4 times the nighttime value. Moreover, OPAHs correlated well with $\mathrm{Abs}_{365}$,WI-BrC in summer during daytime $\left(r^{2}=0.72\right)$ but not during nighttime $\left(r^{2}<0.1\right)$. These results demonstrated that photochemical formation of $\mathrm{BrC}$ and enhanced $\mathrm{BB}$ emissions (e.g., from cooking) contributed to the higher daytime MACs in summer. In winter, the Abs of WS-BrC correlated strongly with relative humidity, sulfate and $\mathrm{NO}_{2}$, suggesting that aqueousphase reactions played an important role in the formation of secondary BrC. Abs 365 , wS-BrC correlated well with the concentrations of nitrophenols in both seasons, suggesting an important contribution of nitrated aromatic compounds to light absorption of WS-BrC. However, this contribution is much lower in summer due to faster photodegradation reactions of these compounds. WS-BrC and WI-BrC were estimated to account for $0.83 \pm 0.23 \%$ and $0.53 \pm 0.33 \%$, respectively, of the total down-welling solar radiation in the UV range in summer and $1.67 \pm 0.72 \%$ and $2.07 \pm 1.24 \%$, respectively, in winter. The substantive contribution of WI$\mathrm{BrC}$ to total $\mathrm{BrC}$ absorption ( $\sim 40 \%$ in summer and $>50 \%$ in winter) emphasizes the important role that WI-BrC likely plays in atmospheric chemistry and the Earth's climate system.

Data availability. Data are available by contacting the corresponding authors.

Supplement. The supplement related to this article is available online at: https://doi.org/10.5194/acp-20-4889-2020-supplement.

Author contributions. JiaL, QZ, GW, KFH and JC designed the experiment. JiaL, GW and KFH arranged the sample collection. JinL, $\mathrm{LaL}$ and $\mathrm{CW}$ collected the samples. JiaL, JinL, JW, WJ and LiL analyzed the samples. JiaL, QZ and GW performed the data interpretation. JiaL, QZ and GW wrote the paper.

Competing interests. The authors declare that they have no conflict of interest.

Special issue statement. This article is part of the special issue "Multiphase chemistry of secondary aerosol formation under severe haze". It is not associated with a conference.

Acknowledgements. This work was financially supported by the National Nature Science Foundation of China (nos. 41773117, 91644102, 41977332, 91543116). Jianjun Li also acknowledged the support of the Youth Innovation Promotion Association CAS (no. 2020407). The authors gratefully acknowledge the National Center for Atmospheric Research for the provision of the solar actinic flux and irradiance data (Quick TUV Calculator, http://cprm.acom.ucar. 
edu/Models/TUV/Interactive_TUV/, last access: 19 March 2019) used in this publication.

Financial support. This research has been supported by the National Nature Science Foundation of China (grant nos. 41773117, 91644102, 41977332, 91543116), and the Youth Innovation Promotion Association CAS (no. 2020407).

Review statement. This paper was edited by Jingkun Jiang and reviewed by three anonymous referees.

\section{References}

Andreae, M. O. and Gelencser, A.: Black carbon or brown carbon? The nature of light-absorbing carbonaceous aerosols, Atmos. Chem. Phys., 6, 3131-3148, https://doi.org/10.5194/acp-63131-2006, 2006.

Chang, J. L. and Thompson, J. E.: Characterization of colored products formed during irradiation of aqueous solutions containing $\mathrm{H}_{2} \mathrm{O}_{2}$ and phenolic compounds, Atmos. Environ., 44, 541-551, https://doi.org/10.1016/j.atmosenv.2009.10.042, 2010.

Chen, Y. and Bond, T. C.: Light absorption by organic carbon from wood combustion, Atmos. Chem. Phys., 10, 1773-1787, https://doi.org/10.5194/acp-10-1773-2010, 2010.

Chen, Y., Ge, X., Chen, H., Xie, X., Chen, Y., Wang, J., Ye, Z., Bao, M., Zhang, Y., and Chen, M.: Seasonal light absorption properties of water-soluble brown carbon in atmospheric fine particles in Nanjing, China, Atmos. Environ., 187, 230-240, https://doi.org/10.1016/j.atmosenv.2018.06.002, 2018.

Cheng, Y., He, K. B., Zheng, M., Duan, F. K., Du, Z. Y., Ma, Y. L., Tan, J. H., Yang, F. M., Liu, J. M., Zhang, X. L., Weber, R. J., Bergin, M. H., and Russell, A. G.: Mass absorption efficiency of elemental carbon and water-soluble organic carbon in Beijing, China, Atmos. Chem. Phys., 11, 11497-11510, https://doi.org/10.5194/acp-11-11497-2011, 2011.

Cheng, Y., Zheng, G., Wei, C., Mu, Q., Zheng, B., Wang, Z., Gao, M., Zhang, Q., He, K., Carmichael, G., Pöschl, U., and Su, H.: Reactive nitrogen chemistry in aerosol water as a source of sulfate during haze events in China, Sci. Adv., 2, e1601530, https://doi.org/10.1126/sciadv.1601530, 2016.

De Haan, D. O., Tapavicza, E., Riva, M., Cui, T. Q., Surratt, J. D., Smith, A. C., Jordan, M. C., Nilakantan, S., Almodovar, M., Stewart, T. N., de Loera, A., De Haan, A. C., Cazaunau, M., Gratien, A., Pangui, E., and Doussin, J. F.: Nitrogen-Containing, Light-Absorbing Oligomers Produced in Aerosol Particles Exposed to Methylglyoxal, Photolysis, and Cloud Cycling, Environ. Sci. Technol., 52, 4061-4071, https://doi.org/10.1021/acs.est.7b06105, 2018.

Desyaterik, Y., Sun, Y., Shen, X., Lee, T., Wang, X., Wang, T., and Collett Jr., J. L.: Speciation of "brown" carbon in cloud water impacted by agricultural biomass burning in eastern China, J. Geophys. Res.-Atmos., 118, 7389-7399, https://doi.org/10.1002/jgrd.50561, 2013.

Du, Z., He, K., Cheng, Y., Duan, F., Ma, Y., Liu, J., Zhang, X., Zheng, M., and Weber, R.: A yearlong study of water-soluble organic carbon in Beijing II: Light absorption properties, Atmos. Environ., 89, 235-241, https://doi.org/10.1016/j.atmosenv.2014.02.022, 2014.

Feng, Y., Ramanathan, V., and Kotamarthi, V. R.: Brown carbon: a significant atmospheric absorber of solar radiation?, Atmos. Chem. Phys., 13, 8607-8621, 10.5194/acp-13-8607-2013, 2013. Guenther, A., Karl, T., Harley, P., Wiedinmyer, C., Palmer, P. I., and Geron, C.: Estimates of global terrestrial isoprene emissions using MEGAN (Model of Emissions of Gases and Aerosols from Nature), Atmos. Chem. Phys., 6, 3181-3210, https://doi.org/10.5194/acp-6-3181-2006, 2006.

Heald, C. L., Henze, D. K., Horowitz, L. W., Feddema, J., Lamarque, J. F., Guenther, A., Hess, P. G., Vitt, F., Seinfeld, J. H., Goldstein, A. H., and Fung, I.: Predicted change in global secondary organic aerosol concentrations in response to future climate, emissions, and land use change, J. Geophys. Res.-Atmos., 113, D05211, https://doi.org/10.1029/2007jd009092, 2008.

Hecobian, A., Zhang, X., Zheng, M., Frank, N., Edgerton, E. S., and Weber, R. J.: Water-Soluble Organic Aerosol material and the light-absorption characteristics of aqueous extracts measured over the Southeastern United States, Atmos. Chem. Phys., 10, 5965-5977, https://doi.org/10.5194/acp-10-5965-2010, 2010.

Huang, R.-J., Zhang, Y., Bozzetti, C., Ho, K.-F., Cao, J.-J., Han, Y., Daellenbach, K. R., Slowik, J. G., Platt, S. M., Canonaco, F., Zotter, P., Wolf, R., Pieber, S. M., Bruns, E. A., Crippa, M., Ciarelli, G., Piazzalunga, A., Schwikowski, M., Abbaszade, G., SchnelleKreis, J., Zimmermann, R., An, Z., Szidat, S., Baltensperger, U., El Haddad, I., and Prevot, A. S. H.: High secondary aerosol contribution to particulate pollution during haze events in China, Nature, 514, 218-222, https://doi.org/10.1038/nature13774, 2014.

Huang, R.-J., Yang, L., Cao, J., Chen, Y., Chen, Q., Li, Y., Duan, J., Zhu, C., Dai, W., Wang, K., Lin, C., Ni, H., Corbin, J. C., Wu, Y., Zhang, R., Tie, X., Hoffmann, T., O'Dowd, C., and Dusek, U.: Brown Carbon Aerosol in Urban Xi'an, Northwest China: The Composition and Light Absorption Properties, Environ. Sci. Technol., 52, 6825-6833, https://doi.org/10.1021/acs.est.8b02386, 2018.

Jacobson, M. Z.: Studying the effects of aerosols on vertical photolysis rate coefficient and temperature profiles over an urban airshed, J. Geophys. Res.-Atmos., 103, 10593-10604, https://doi.org/10.1029/98jd00287, 1998.

Jiang, Q., Sun, Y. L., Wang, Z., and Yin, Y.: Aerosol composition and sources during the Chinese Spring Festival: fireworks, secondary aerosol, and holiday effects, Atmos. Chem. Phys., 15, 6023-6034, https://doi.org/10.5194/acp-15-6023-2015, 2015.

Kim, H., Kim, J. Y., Jin, H. C., Lee, J. Y., and Lee, S. P.: Seasonal variations in the light-absorbing properties of water-soluble and insoluble organic aerosols in Seoul, Korea, Atmos. Environ., 129 , 234-242, https://doi.org/10.1016/j.atmosenv.2016.01.042, 2016.

Kirchstetter, T. W. and Thatcher, T. L.: Contribution of organic carbon to wood smoke particulate matter absorption of solar radiation, Atmos. Chem. Phys., 12, 6067-6072, https://doi.org/10.5194/acp-12-6067-2012, 2012.

Kirchstetter, T. W., Novakov, T., and Hobbs, P. V.: Evidence that the spectral dependence of light absorption by aerosols is affected by organic carbon, J. Geophys. Res.-Atmos., 109, D21208, https://doi.org/10.1029/2004JD004999, 2004

Kirillova, E. N., Andersson, A., Han, J., Lee, M., and Gustafsson, Ö.: Sources and light absorption of water-soluble organic carbon aerosols in the outflow from northern China, Atmos. 
Chem. Phys., 14, 1413-1422, https://doi.org/10.5194/acp-141413-2014, 2014a.

Kirillova, E. N., Andersson, A., Tiwari, S., Srivastava, A. K., Bisht, D. S., and Gustafsson, Ö.: Water-soluble organic carbon aerosols during a full New Delhi winter: Isotope-based source apportionment and optical properties, J. Geophys. Res.-Atmos., 119, 3476-3485, https://doi.org/10.1002/2013jd020041, 2014b.

Kirillova, E. N., Marinoni, A., Bonasoni, P., Vuillermoz, E., Facchini, M. C., Fuzzi, S., and Decesari, S.: Light absorption properties of brown carbon in the high Himalayas, J. Geophys. Res.Atmos., 121, 9621-9639, https://doi.org/10.1002/2016jd025030, 2016.

Kitanovski, Z., Grgić, I., Vermeylen, R., Claeys, M., and Maenhaut, W.: Liquid chromatography tandem mass spectrometry method for characterization of monoaromatic nitro-compounds in atmospheric particulate matter, J. Chromatogr. A, 1268, 35-43, https://doi.org/10.1016/j.chroma.2012.10.021, 2012.

Kitanovski, Z., Čusak, A., Grgić, I., and Claeys, M.: Chemical characterization of the main products formed through aqueous-phase photonitration of guaiacol, Atmos. Meas. Tech., 7, 2457-2470, https://doi.org/10.5194/amt-7-2457-2014, 2014.

Kondo, Y., Miyazaki, Y., Takegawa, N., Miyakawa, T., Weber, R. J., Jimenez, J. L., Zhang, Q., and Worsnop, D. R.: Oxygenated and water-soluble organic aerosols in Tokyo, J. Geophys. Res., 112, D01203, https://doi.org/10.1029/2006jd007056, https://doi.org/10.1029/2006jd007056, 2007.

Laskin, A., Laskin, J., and Nizkorodov, S. A.: Chemistry of Atmospheric Brown Carbon, Chem. Rev., 115, 4335-4382, https://doi.org/10.1021/cr5006167, 2015.

Laskin, J., Laskin, A., Roach, P. J., Slysz, G. W., Anderson, G. A., Nizkorodov, S. A., Bones, D. L., and Nguyen, L. Q.: High-Resolution Desorption Electrospray Ionization Mass Spectrometry for Chemical Characterization of Organic Aerosols, Anal. Chem., 82, 2048-2058, https://doi.org/10.1021/ac902801f, 2010.

Lee, H. J., Aiona, P. K., Laskin, A., Laskin, J., and Nizkorodov, S. A.: Effect of Solar Radiation on the Optical Properties and Molecular Composition of Laboratory Proxies of Atmospheric Brown Carbon, Environ. Sci. Technol., 48, 1021710226, https://doi.org/10.1021/es502515r, 2014.

Li, J., Wang, G., Aggarwal, S. G., Huang, Y., Ren, Y., Zhou, B., Singh, K., Gupta, P. K., Cao, J., and Zhang, R.: Comparison of abundances, compositions and sources of elements, inorganic ions and organic compounds in atmospheric aerosols from Xi' an and New Delhi, two megacities in China and India, Sci. Total Environ., 476/477, 485-495, https://doi.org/10.1016/j.scitotenv.2014.01.011, 2014.

Li, J. J.: Chemical Composition, Size distribution and Source Apportionment of Atmospheric Aerosols at an Alpine Site in Guanzhong Plain, China, Ph. D, Xi'an Jiaotong University, Xi'an, 124 pp., 2011 (in Chinese).

Li, X., Chen, Y., and Bond, T. C.: Light absorption of organic aerosol from pyrolysis of corn stalk, Atmos. Environ., 144, 249256, https://doi.org/10.1016/j.atmosenv.2016.09.006, 2016a.

Li, X., Jiang, L., Hoa, L. P., Lyu, Y., Xu, T. T., Yang, X., Iinuma, Y., Chen, J. M., and Herrmann, H.: Size distribution of particle-phase sugar and nitrophenol tracers during severe urban haze episodes in Shanghai, Atmos. Environ., 145, 115-127, https://doi.org/10.1016/j.atmosenv.2016.09.030, 2016 b.
Lin, P., Liu, J., Shilling, J. E., Kathmann, S. M., Laskin, J., and Laskin, A.: Molecular characterization of brown carbon (BrC) chromophores in secondary organic aerosol generated from photo-oxidation of toluene, Phys. Chem. Chem. Phys., 17, 23312-23325, https://doi.org/10.1039/c5cp02563j, 2015.

Lin, P., Bluvshtein, N., Rudich, Y., Nizkorodov, S. A., Laskin, J., and Laskin, A.: Molecular Chemistry of Atmospheric Brown Carbon Inferred from a Nationwide Biomass Burning Event, Environ. Sci. Technol., 51, 11561-11570, https://doi.org/10.1021/acs.est.7b02276, 2017.

Lin, Y.-H., Budisulistiorini, S. H., Chu, K., Siejack, R. A., Zhang, H., Riva, M., Zhang, Z., Gold, A., Kautzman, K. E., and Surratt, J. D.: Light-Absorbing Oligomer Formation in Secondary Organic Aerosol from Reactive Uptake of Isoprene Epoxydiols, Environ. Sci. Technol., 48, 12012-12021, https://doi.org/10.1021/es503142b, 2014.

Liu, J., Bergin, M., Guo, H., King, L., Kotra, N., Edgerton, E., and Weber, R. J.: Size-resolved measurements of brown carbon in water and methanol extracts and estimates of their contribution to ambient fine-particle light absorption, Atmos. Chem. Phys., 13, 12389-12404, https://doi.org/10.5194/acp-13-123892013, 2013.

Liu, J., Lin, P., Laskin, A., Laskin, J., Kathmann, S. M., Wise, M., Caylor, R., Imholt, F., Selimovic, V., and Shilling, J. E.: Optical properties and aging of light-absorbing secondary organic aerosol, Atmos. Chem. Phys., 16, 12815-12827, https://doi.org/10.5194/acp-16-12815-2016, 2016.

Liu, J., Mo, Y., Ding, P., Li, J., Shen, C., and Zhang, G.: Dual carbon isotopes (C-14 and C-13) and optical properties of WSOC and HULIS-C during winter in Guangzhou, China, Sci. Total Environ., 633, 1571-1578, https://doi.org/10.1016/j.scitotenv.2018.03.293, 2018.

Liu, P. F., Abdelmalki, N., Hung, H. M., Wang, Y., Brune, W. H., and Martin, S. T.: Ultraviolet and visible complex refractive indices of secondary organic material produced by photooxidation of the aromatic compounds toluene and $m$-xylene, Atmos. Chem. Phys., 15, 1435-1446, https://doi.org/10.5194/acp15-1435-2015, 2015.

Lu, J. W., Flores, J. M., Lavi, A., Abo-Riziq, A., and Rudich, Y.: Changes in the optical properties of benzo[a]pyrenecoated aerosols upon heterogeneous reactions with $\mathrm{NO}_{2}$ and $\mathrm{NO}_{3}$, Phys. Chem. Chem. Phys., 13, 6484-6492, https://doi.org/10.1039/C0CP02114H, 2011.

Mohr, C., Lopez-Hilfiker, F. D., Zotter, P., Prévôt, A. S. H., Xu, L., Ng, N. L., Herndon, S. C., Williams, L. R., Franklin, J. P., Zahniser, M. S., Worsnop, D. R., Knighton, W. B., Aiken, A. C., Gorkowski, K. J., Dubey, M. K., Allan, J. D., and Thornton, J. A.: Contribution of Nitrated Phenols to Wood Burning Brown Carbon Light Absorption in Detling, United Kingdom during Winter Time, Environ. Sci. Technol., 47, 6316-6324, https://doi.org/10.1021/es400683v, 2013.

Moschos, V., Kumar, N. K., Daellenbach, K. R., Baltensperger, U., Prévôt, A. S. H., and El Haddad, I.: Source Apportionment of Brown Carbon Absorption by Coupling Ultraviolet-Visible Spectroscopy with Aerosol Mass Spectrometry, Environ. Sci. Technol. Lett., 5, 302-308, https://doi.org/10.1021/acs.estlett.8b00118, 2018.

Nakayama, T., Sato, K., Matsumi, Y., Imamura, T., Yamazaki, A., and Uchiyama, A.: Wavelength Dependence of Refrac- 
tive Index of Secondary Organic Aerosols Generated during the Ozonolysis and Photooxidation of \&alpha;-Pinene, Scientific Online Letters on the Atmosphere, 8, 119-123, https://doi.org/10.2151/sola.2012-030, 2012.

Nakayama, T., Sato, K., Tsuge, M., Imamura, T., and Matsumi, Y.: Complex refractive index of secondary organic aerosol generated from isoprene $/ \mathrm{NO}_{x}$ photooxidation in the presence and absence of $\mathrm{SO}_{2}$, J. Geophys. Res.-Atmos., 120, 7777-7787, https://doi.org/10.1002/2015jd023522, 2015.

Nguyen, T. B., Lee, P. B., Updyke, K. M., Bones, D. L., Laskin, J., Laskin, A., and Nizkorodov, S. A.: Formation of nitrogen- and sulfur-containing light-absorbing compounds accelerated by evaporation of water from secondary organic aerosols, J. Geophys. Res.-Atmos., 117, D01207, https://doi.org/10.1029/2011jd016944, 2012.

Nozière, B. and Esteve, W.: Organic reactions increasing the absorption index of atmospheric sulfuric acid aerosols, Geophys. Res. Lett., 32, L03812, https://doi.org/10.1029/2004GL021942, 2005.

Nozière, B., Dziedzic, P., and Córdova, A.: Formation of secondary light-absorbing "fulvic-like" oligomers: A common process in aqueous and ionic atmospheric particles?, Geophys. Res. Lett., 34, L21812, https://doi.org/10.1029/2007GL031300, 2007.

Ofner, J., Krüger, H. U., Grothe, H., Schmitt-Kopplin, P., Whitmore, K., and Zetzsch, C.: Physico-chemical characterization of SOA derived from catechol and guaiacol - a model substance for the aromatic fraction of atmospheric HULIS, Atmos. Chem. Phys., 11, 1-15, https://doi.org/10.5194/acp-11-1-2011, 2011.

Park, S. S. and Yu, J.: Chemical and light absorption properties of humic-like substances from biomass burning emissions under controlled combustion experiments, Atmos. Environ., 136, 114122, https://doi.org/10.1016/j.atmosenv.2016.04.022, 2016.

Powelson, M. H., Espelien, B. M., Hawkins, L. N., Galloway, M. M., and De Haan, D. O.: Brown Carbon Formation by Aqueous-Phase Carbonyl Compound Reactions with Amines and Ammonium Sulfate, Environ. Sci. Technol., 48, 985-993, https://doi.org/10.1021/es4038325, 2014.

Rizzo, L. V., Correia, A. L., Artaxo, P., Procópio, A. S., and Andreae, M. O.: Spectral dependence of aerosol light absorption over the Amazon Basin, Atmos. Chem. Phys., 11, 8899-8912, https://doi.org/10.5194/acp-11-8899-2011, 2011.

Rizzo, L. V., Artaxo, P., Müller, T., Wiedensohler, A., Paixão, M., Cirino, G. G., Arana, A., Swietlicki, E., Roldin, P., Fors, E. O., Wiedemann, K. T., Leal, L. S. M., and Kulmala, M.: Long term measurements of aerosol optical properties at a primary forest site in Amazonia, Atmos. Chem. Phys., 13, 2391-2413, https://doi.org/10.5194/acp-13-2391-2013, 2013.

Romonosky, D. E., Laskin, A., Laskin, J., and Nizkorodov, S. A.: High-Resolution Mass Spectrometry and Molecular Characterization of Aqueous Photochemistry Products of Common Types of Secondary Organic Aerosols, J. Phys. Chem. A, 119, 25942606, https://doi.org/10.1021/jp509476r, 2015.

Samburova, V., Connolly, J., Gyawali, M., Yatavelli, R. L. N., Watts, A. C., Chakrabarty, R. K., Zielinska, B., Moosmüller, H., and Khlystov, A.: Polycyclic aromatic hydrocarbons in biomass-burning emissions and their contribution to light absorption and aerosol toxicity, Sci. Total Environ., 568, 391-401, https://doi.org/10.1016/j.scitotenv.2016.06.026, 2016.
Sengupta, D., Samburova, V., Bhattarai, C., Kirillova, E., Mazzoleni, L., Iaukea-Lum, M., Watts, A., Moosmuller, H., and Khlystov, A.: Light absorption by polar and non-polar aerosol compounds from laboratory biomass combustion, Atmos. Chem. Phys., 18, 10849-10867, https://doi.org/10.5194/acp-18-108492018, 2018.

Shen, Z., Zhang, Q., Cao, J., Zhang, L., Lei, Y., Huang, Y., Huang, R. J., Gao, J., Zhao, Z., Zhu, C., Yin, X., Zheng, C., Xu, H., and Liu, S.: Optical properties and possible sources of brown carbon in $\mathrm{PM}_{2.5}$ over Xi' an, China, Atmos. Environ., 150, 322330, https://doi.org/10.1016/j.atmosenv.2016.11.024, 2017.

Simoneit, B. R. T.: Biomass burning - A review of organic tracers for smoke from incomplete combustion, Appl. Geochem., 17, 129-162, 2002.

Smith, J. D., Kinney, H., and Anastasio, C.: Phenolic carbonyls undergo rapid aqueous photodegradation to form lowvolatility, light-absorbing products, Atmos. Environ., 126, 3644, https://doi.org/10.1016/j.atmosenv.2015.11.035, 2016.

Sumlin, B. J., Pandey, A., Walker, M. J., Pattison, R. S., Williams, B. J., and Chakrabarty, R. K.: Atmospheric Photooxidation Diminishes Light Absorption by Primary Brown Carbon Aerosol from Biomass Burning, Environ. Sci. Technol. Lett., 4, 540-545, https://doi.org/10.1021/acs.estlett.7b00393, 2017.

Sun, H., Biedermann, L., and Bond, T. C.: Color of brown carbon: A model for ultraviolet and visible light absorption by organic carbon aerosol, Geophys. Res. Lett., 34, L17813, https://doi.org/10.1029/2007g1029797, 2007.

Teich, M., van Pinxteren, D., Wang, M., Kecorius, S., Wang, Z., Müller, T., Močnik, G., and Herrmann, H.: Contributions of nitrated aromatic compounds to the light absorption of watersoluble and particulate brown carbon in different atmospheric environments in Germany and China, Atmos. Chem. Phys., 17, 1653-1672, https://doi.org/10.5194/acp-17-1653-2017, 2017.

Tran, A., Williams, G., Younus, S., Ali, N. N., Blair, S. L., Nizkorodov, S. A., and Al-Abadleh, H. A.: Efficient Formation of Light-Absorbing Polymeric Nanoparticles from the Reaction of Soluble $\mathrm{Fe}(\mathrm{III})$ with $\mathrm{C}_{4}$ and $\mathrm{C}_{6}$ Dicarboxylic Acids, Environ. Sci. Technol., 51, 9700-9708, https://doi.org/10.1021/acs.est.7b01826, 2017.

Updyke, K. M., Nguyen, T. B., and Nizkorodov, S. A.: Formation of brown carbon via reactions of ammonia with secondary organic aerosols from biogenic and anthropogenic precursors, Atmos. Environ., 63, 22-31, https://doi.org/10.1016/j.atmosenv.2012.09.012, 2012.

van Donkelaar, A., Martin, R. V., Brauer, M., Kahn, R., Levy, R., Verduzco, C., and Villeneuve, P. J.: Global Estimates of Ambient Fine Particulate Matter Concentrations from Satellite-Based Aerosol Optical Depth: Development and Application, Environ. Health Persp., 118, 847-855, https://doi.org/10.1289/ehp.0901623, 2010.

Wang, G. H., Zhang, R. Y., Gomez, M. E., Yang, L. X., Zamora, M. L., Hu, M., Lin, Y., Peng, J. F., Guo, S., Meng, J. J., Li, J. J., Cheng, C. L., Hu, T. F., Ren, Y. Q., Wang, Y. S., Gao, J., Cao, J. J., An, Z. S., Zhou, W. J., Li, G. H., Wang, J. Y., Tian, P. F., Marrero-Ortiz, W., Secrest, J., Du, Z. F., Zheng, J., Shang, D. J., Zeng, L. M., Shao, M., Wang, W. G., Huang, Y., Wang, Y., Zhu, Y. J., Li, Y. X., Hu, J. X., Pan, B., Cai, L., Cheng, Y. T., Ji, Y. M., Zhang, F., Rosenfeld, D., Liss, P. S., Duce, R. A., Kolb, C. E., and Molina, M. J.: Persistent sulfate formation from London Fog 
to Chinese haze, P. Natl. Acad. Sci. USA, 113, 13630-13635, https://doi.org/10.1073/pnas.1616540113, 2016.

Washenfelder, R. A., Attwood, A. R., Brock, C. A., Guo, H., Xu, L., Weber, R. J., Ng, N. L., Allen, H. M., Ayres, B. R., Baumann, K., Cohen, R. C., Draper, D. C., Duffey, K. C., Edgerton, E., Fry, J. L., Hu, W. W., Jimenez, J. L., Palm, B. B., Romer, P., Stone, E. A., Wooldridge, P. J., and Brown, S. S.: Biomass burning dominates brown carbon absorption in the rural southeastern United States, Geophys. Res. Lett., 42, 653-664, https://doi.org/10.1002/2014GL062444, 2015.

Wu, C.: Seasonal variation of atmospheric acidic and basic species and the characteristics of gas-particle partition in a typical city of Guanzhong Basin, Ph. D, The University of Chinese Academy of Sciences, The University of Chinese Academy of Sciences, Xi' an, 2018 (in Chinese).

Wu, C., Wang, G., Wang, J., Li, J., Ren, Y., Zhang, L., Cao, C., Li, J., Ge, S., Xie, Y., Wang, X., and Xue, G.: Chemical characteristics of haze particles in Xi' an during Chinese Spring Festival: Impact of fireworks burning, J. Environ. Sci., 71, 179-187, https://doi.org/10.1016/j.jes.2018.04.008, 2018.

Wu, C., Wang, G., Li, J., Li, J., Cao, C., Ge, S., Xie, Y., Chen, J., Li, X., Xue, G., Wang, X., Zhao, Z., and Cao, F.: The characteristics of atmospheric brown carbon in Xi' an, inland China: sources, size distributions and optical properties, Atmos. Chem. Phys., 20, 2017-2030, https://doi.org/10.5194/acp-20-2017-2020, 2020.

Wu, G., Ram, K., Fu, P., Wang, W., Zhang, Y., Liu, X., Stone, E. A., Pradhan, B. B., Dangol, P. M., Panday, A. K., Wan, X., Bai, Z., Kang, S., Zhang, Q., and Cong, Z.: Water-Soluble Brown Carbon in Atmospheric Aerosols from Godavari (Nepal), a Regional Representative of South Asia, Environ. Sci. Technol., 53, 34713479, https://doi.org/10.1021/acs.est.9b00596, 2019.

Xie, M., Chen, X., Hays, M. D., and Holder, A. L.: Composition and light absorption of N-containing aromatic compounds in organic aerosols from laboratory biomass burning, Atmos. Chem. Phys., 19, 2899-2915, https://doi.org/10.5194/acp-192899-2019, 2019.

Xu, J., Cui, T. Q., Fowler, B., Fankhauser, A., Yang, K., Surratt, J. D., and McNeill, V. F.: Aerosol Brown Carbon from Dark Reactions of Syringol in Aqueous Aerosol Mimics, ACS Earth Sp. Chem., 2, 608-617, https://doi.org/10.1021/acsearthspacechem.8b00010, 2018.
Xu, J., Hettiyadura, A. P. S., Liu, Y., Zhang, X., Kang, S., and Laskin, A.: Regional Differences of Chemical Composition and Optical Properties of Aerosols in the Tibetan Plateau, J. Geophys. Res.-Atmos., 125, e2019JD031226, https://doi.org/10.1029/2019jd031226, 2020.

Yan, C., Zheng, M., Sullivan, A. P., Bosch, C., Desyaterik, Y., Andersson, A., Li, X., Guo, X., Zhou, T., Gustafsson, Ö., and Collett, J. L.: Chemical characteristics and lightabsorbing property of water-soluble organic carbon in Beijing: Biomass burning contributions, Atmos. Environ., 121, 4-12, https://doi.org/10.1016/j.atmosenv.2015.05.005, 2015a.

Yan, C., Zheng, M., Sullivan, A. P., Bosch, C., Desyaterik, Y., Andersson, A., Li, X., Guo, X., Zhou, T., Gustafsson, O., and Collett Jr., J. L.: Chemical characteristics and lightabsorbing property of water-soluble organic carbon in Beijing: Biomass burning contributions, Atmos. Environ., 121, 4-12, https://doi.org/10.1016/j.atmosenv.2015.05.005, 2015 b.

Yan, C. Q., Zheng, M., Bosch, C., Andersson, A., Desyaterik, Y., Sullivan, A. P., Collett, J. L., Zhao, B., Wang, S. X., He, K. B., and Gustafsson, O.: Important fossil source contribution to brown carbon in Beijing during winter, Sci. Rep., 7, 43182, https://doi.org/10.1038/srep43182, 2017.

Yu, L., Smith, J., Laskin, A., Anastasio, C., Laskin, J., and Zhang, Q.: Chemical characterization of SOA formed from aqueousphase reactions of phenols with the triplet excited state of carbonyl and hydroxyl radical, Atmos. Chem. Phys., 14, 1380113816, https://doi.org/10.5194/acp-14-13801-2014, 2014.

Zhang, X., Lin, Y.-H., Surratt, J. D., and Weber, R. J.: Sources, Composition and Absorption Ångström Exponent of Lightabsorbing Organic Components in Aerosol Extracts from the Los Angeles Basin, Environ. Sci. Technol., 47, 3685-3693, https://doi.org/10.1021/es305047b, 2013.

Zhao, R., Lee, A. K. Y., Huang, L., Li, X., Yang, F., and Abbatt, J. P. D.: Photochemical processing of aqueous atmospheric brown carbon, Atmos. Chem. Phys., 15, 6087-6100, https://doi.org/10.5194/acp-15-6087-2015, 2015. 